\title{
New evidences about human activities during the first part of the Upper Pleniglacial in Ukraine from zooarchaeological studies
}

\author{
L. Demay a, b, *, V.I. Belyaeva ${ }^{\text {c }}$, L.V. Kulakovksa ${ }^{\text {d, }}$ M. Patou-Mathis ${ }^{\text {b }}$, S. Péan ${ }^{\text {b }}$, \\ D.V. Stupak ${ }^{\mathrm{e}}$, P.M. Vasil'ev ${ }^{\mathrm{d}}$, M. Otte ${ }^{\mathrm{a}}$, P. Noiret $^{\mathrm{a}}$ \\ a University of Liege (Belgium), Service of Prehistory, 7 place du xx Août, bât A1, B-4000, Liège, Belgium \\ ${ }^{\mathrm{b}}$ National Museum of Natural History (France), UMR 7194 CNRS "Histoire Naturelle de l'Homme Préhistorique", Prehistory Department, 1, \\ rue René Panhard, 75013, Paris, France \\ c St.-Petersburg State University, 7-9, Universitetskaya nab., 199034, St.Petersburg, Russia \\ ${ }^{\mathrm{d}}$ NAS Museum of Archaeology, National Museum of Natural History, 15 B. Khmelnytskoho St., 01601, Kyiv, Ukraine \\ e NAS Institute of Archaeology, 12 Heroyiv Stalingradu Ave., 04210, Kyiv, Ukraine
}

\section{A R T I C L E I N F O}

\section{Article history:}

Available online 11 April 2016

\section{Keywords:}

Upper Pleniglacial

Gravettian

Epigravettian

Ukraine

\begin{abstract}
A B S T R A C T
The Upper Pleniglacial, between $23000-20000 \mathrm{BP}$, is characterized by the intensification of cold climate and is followed by the maximum extent of ice sheets. There is a little bit information about the human activities during this period. New archaeological excavations in Ukraine permit to evidence data about behavioural human adaptations. These open air sites are on the one hand Pushkari 1 (excavation VII), Pogon (excavation VII) and Obollonia in the Desna valley and on the other hand Dorochivtsy III in the Dniester valley. These sites are characterised by atypical lithic industries made on local flint relied to the Gravettian but containing Epigravettian or Aurignacoid elements. In order to better understand the subsistence strategy we carried out zooarchaeological and taphonomical studies, which allow us to reveal the strategy of fauna exploitation by the human groups. We highlighted that all these sites are characterized by a restricted faunal spectrum with the presence of mammoth, reindeer, horse and carnivores (mainly fox [Vulpes vulpes and Alopex lagopus] and wolf). In the Dniester valley the reindeer was the most exploited, whereas the mammoth is the most exploited in the Desna valley. Indeed, it was probably hunt in Pushkari 1, maybe in Pogon and Obollonia. It was exploited as combustible, food resources and bones as raw material. In Dorochivtsy III/6 ivory was used to make tools and as artistic support. Indeed this site and Obollonia present grooved ivory points, this is the oldest occurrence of this kind of artefacts in the both regions. Moreover two engraved tusks presenting more or less figurative pictures were found in Dorochivtsy II//.6 and Obollonia. The other large herbivores were also consumed and carnivores were exploited for their pelts in all these sites. The settlements are recurrent camps with little development occupied during varied seasons oriented to hunting and butchering activities linked with exploitation of local flint. These sites demonstrate the continuity of human occupations within the Eastern European plain, with the persistence of hunting methods and the relative diversity of animal exploitation, during the Upper Pleniglacial. These sites are really important for the understanding of cultural processes in the Eastern European Upper Palaeolithic, and particularly for the understanding of Epigravettian origin.
\end{abstract}

() 2015 Elsevier Ltd and INQUA. All rights reserved.

\footnotetext{
* Corresponding author. National Museum of Natural History (France), UMR 7194 CNRS “Histoire Naturelle de l'Homme Préhistorique”, Prehistory Department, 1, rue René Panhard, 75013, Paris, France.

E-mail addresses: laetitia.demay@student.ulg.ac.be, ldemay@mnhn.fr (L. Demay).
}

\section{Introduction}

This article focuses on the East European plain, delimited by the Urals, Caucasus and Carpathians Mountains and the FennoScandinavian ice-sheet. Within this area, Ukraine has yielded numerous Palaeolithic archaeological sites.

The late middle Pleniglacial is marked by significant climatic deterioration shown by a tundra gley (Fig. 1), demonstrating active 
permafrost. In Eastern Europe, the interpleniglacial paleosols between 28000 and 23000 BP are known as Bryansk paleosols (Velichko and Morozova, 1972; Rusakov and Korkka, 2004). They correspond to Dofinovo paleosols as described by Ukrainian authors (Djindjian et al., 1999). The upper Pleniglacial, MIS 2, begins with loess following this gley (Haesaerts et al. 1998), about 26000 BP. Climatic conditions deteriorate, and particularly after $23000 \mathrm{BP}$, temperatures dropped and aridity increased. A large loess deposit covered Europe as far as the Mediterranean coast.

The subdivisions of this period vary according to authors. For some (Clark et al., 2001; Renssen et al., 2001) the upper Pleniglacial ends with the Bölling oscillation, at $13500 \mathrm{BP}$ and then transitions to the Holocene period. For others (Velichko and Kurenkova, 1990; Covalenco, 1995; Stepanchuk, 1999), the Ostashkovo phase, extends to $16000 \mathrm{BP}$, with the maximum extension of the ice sheet between 20000 and $18000 \mathrm{BP}$, and is followed by the Late Glacial. According to the work of Haesaerts et al. (2003) and Borziac et al. (2005) the Pleniglacial is divided in three phases:

- The first part of the Upper Pleniglacial (26 000-20 000 years BP)

- The second part of the Upper Pleniglacial (20 000-14 000 years $\mathrm{BP})$

- The final phase of the Upper Pleniglacial, Holocene transition (14 000-10 000 years BP)

We are particularly interested in the beginning of the first part of Upper Pleniglacial. There is little information on the human activities during this period. Moreover, the transition between Gravettian and Epigravettian cultures took place during this time.

\section{Archaeological sites}

New archaeological excavations in Ukraine have yielded data about behavioural human adaptations. Here, we present information obtained on four open air sites: in the Desna valley with Pushkari 1 and Pogon (Pushkari complex), and Obollonia; and in the Dniester valley with Dorochivtsy III, recently excavated (Fig. 2).

\subsection{The Desna valley}

\subsubsection{Pushkari complex (Pushkari 1 and Pogon)}

The archaeological complex of Pushkari is located in Eastern Ukraine near the village of Pushkari. It was discovered in 1932 by Rudinski (1947), on the right bank of the Desna river. A.J. Rudinski excavated the Pushkari 1 site (Paseka) in 1932 and 1933 (excavation I) (Rudinski, 1947). Then, excavations from 1937 to 1939 (excavations II, III, IV) were directed by Boriskovski (1949) and since 1981 by V.I. Belyaeva (excavations V, VI, VII). We focus here on the excavation number VII ( $42 \mathrm{~m}^{2}$ excavations) identified by surveys made by Gribchenko in 1996, 1997 and 1998 and excavated by V.I. Belyaeva and P.M. Vasil'ev since 1998. Faunal remains recovered by A.J. Rudinski and R.I. Boriskovski were lost and the material of the excavation number $\mathrm{V}$ was destroyed by fire in the museum of Novgorod Severski in 2007.

The Pogon site, also called Pushkari 8, was discovered in 1940 by Voevodski (1950). M. V. Voevodski excavated the site in 1940 and $1946\left(63 \mathrm{~m}^{2}\right)$. It has been excavated by P. M. Vasil'ev since 2011 $\left(8 \mathrm{~m}^{2}\right)$ (Fig. 3).

The geological studies of Pushkari 1 and Pogon were conducted by Velichko et al. $(1997,1999)$ and Gribchenko (2006) (Fig. 7). These sites are characterized by one cultural level. The layers are located in thick loess deposits in a geological layer situated above the Briansk soil that corresponds to the end of the MIS 3. Therefore, the archaeological layers correspond to the beginning of MIS 2 .

A bone from the archaeological layer of Pushkari 1 was dated to $16775 \pm 605$ (OC 899) BP. However, Velichko (1961), Velichko et al. (1997) and Velichko and Zelikson (2005) thought that this date was questionable, too recent considering the stratigraphical context.

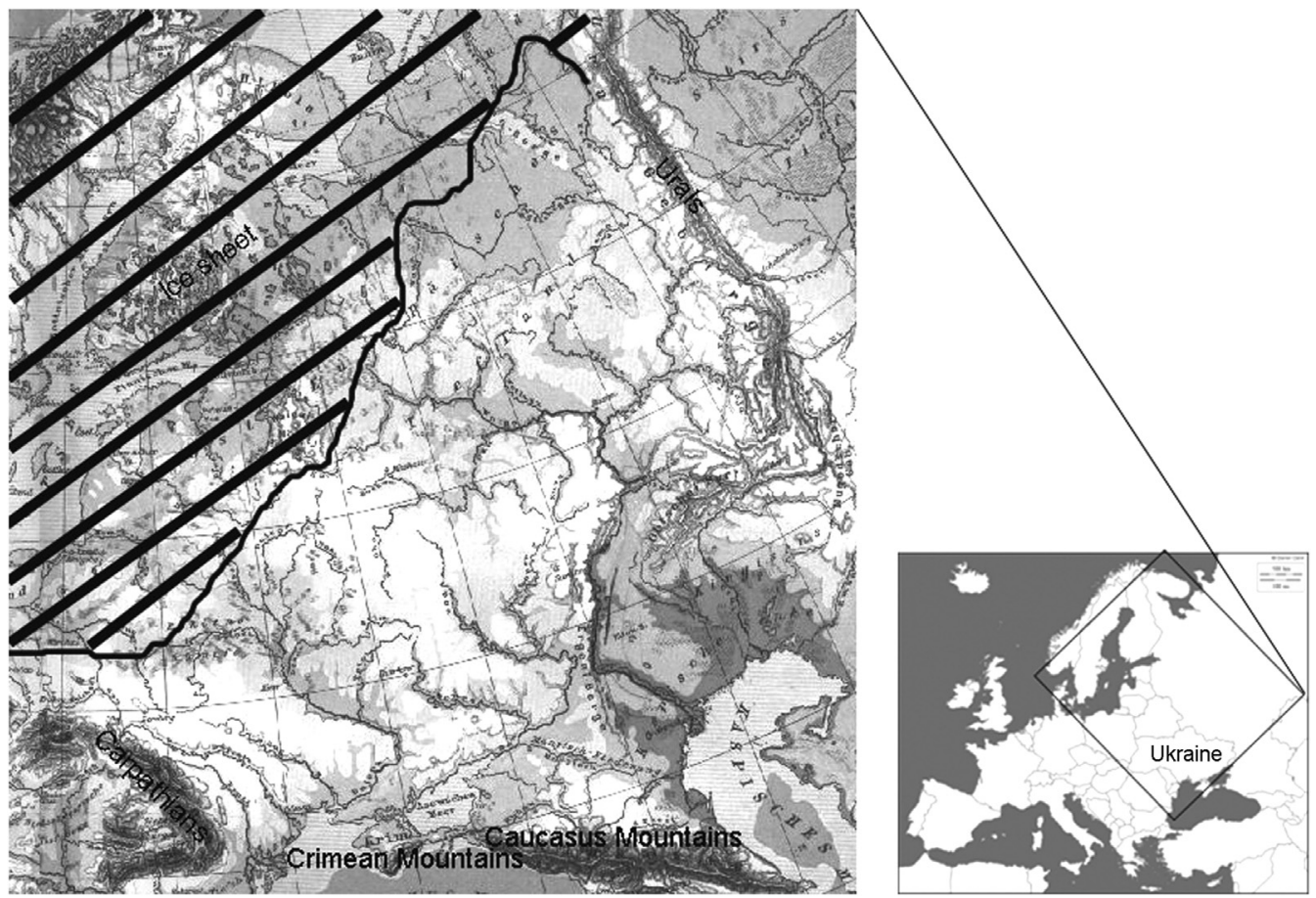

Fig. 1. Geographical context of Eastern Europe during the Upper Pleniglacial. (after Diercke Schul-Atlas für Höhere Lehranstalten, 1907). 


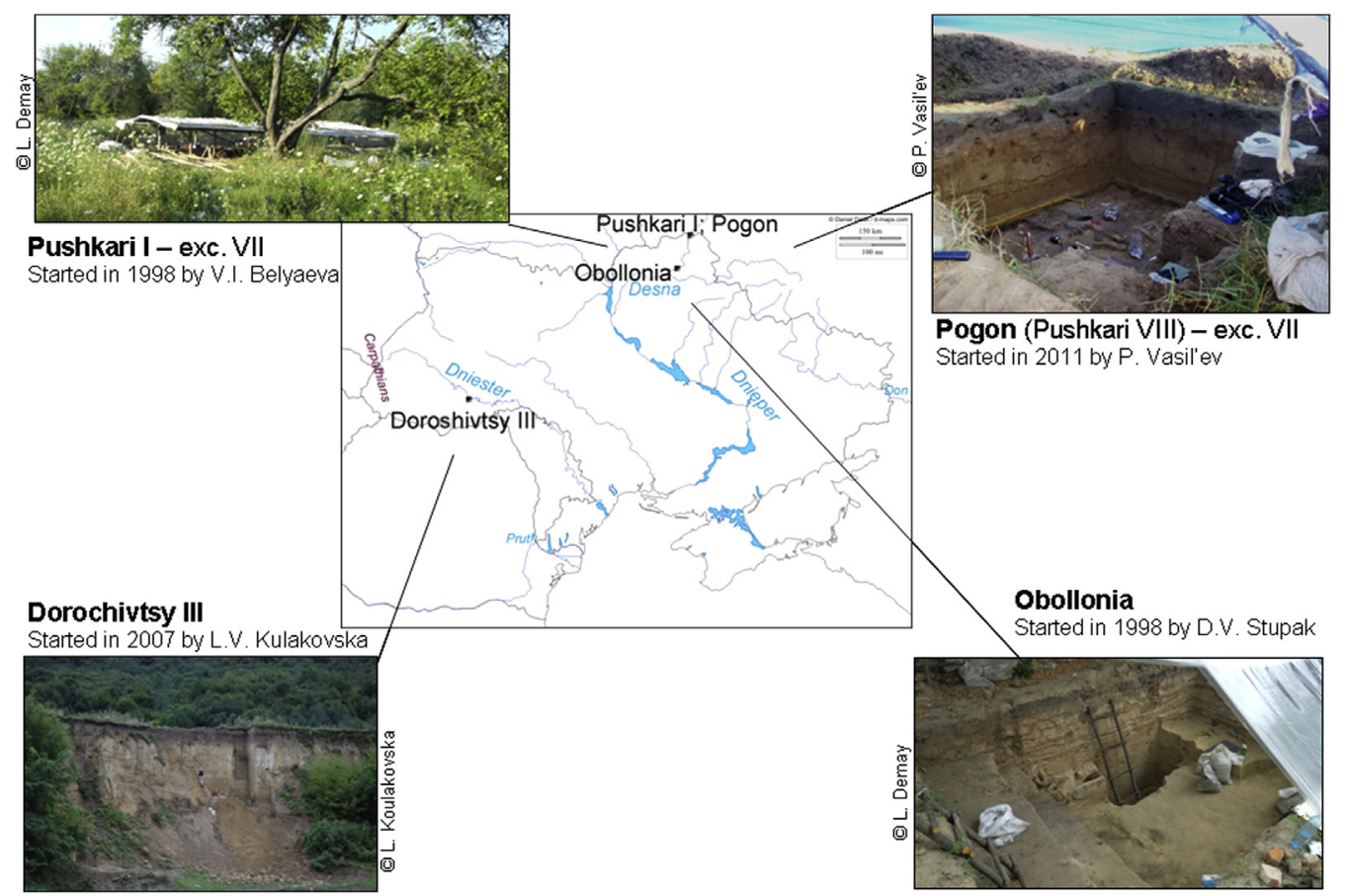

Fig. 2. Geographical location of the studied sites.

The latest results have yielded older dates, between 21000 and 19000 BP (Belyaeva, 2002; Gribchenko et al., 2011) (Table 1). The site of Pogon is dated around 24000 and $22000 \mathrm{BP}$ (Gribchenko, 2006, 2011) (Table 1). wetlands. The landscape was open and dominated by steppe-tundra, with the proximity of forest cover and a relatively wet climate. In Pogon, herbaceous taxa (Poaceae sp., Cyperaceae sp., Ranunculaceae sp.) dominate, which is typical of a cold steppe (Ephedra sp., Artemisia

Table 1

Radiocarbon dates of the studied sites.

\begin{tabular}{|c|c|c|c|c|c|}
\hline Sites & & Dating (BP) & References & Material & Bibliography \\
\hline \multirow[t]{15}{*}{ Pushkari 1} & excavation II & $16775 \pm 605$ & QC899 & Burned bone & Belyaeva, 2002; Gribchenko et al., 2011 \\
\hline & excavation $\mathrm{V}$ & $19010 \pm 220$ & AA1389 & Burned bone & \\
\hline & & $20500 \pm 500$ & GIN11311b & Bone & \\
\hline & & $20900 \pm 900$ & GIN11311a & Bone & \\
\hline & & $20600 \pm 1200$ & GIN8529 & Mammoth tooth & \\
\hline & & $20700 \pm 500$ & GIN8529a & Mammoth tooth & \\
\hline & & $21000 \pm 400$ & GIN3382 & Bone & \\
\hline & & $21100 \pm 400$ & GIN3381 & Burned bone & \\
\hline & & $22350 \pm 150$ & GIN11307 & Burned bone & \\
\hline & excavation VII & $19500 \pm 240$ & Ki11901 & Horse bone & \\
\hline & & $20160 \pm 180$ & GIN11310 & Burned bone & \\
\hline & & $20350 \pm 180$ & GIN10195 & Burned bone & \\
\hline & & $20500 \pm 500$ & GIN11311 & Mammoth tooth & \\
\hline & & $20840 \pm 190$ & GIN11309 & Burned bone & \\
\hline & & $20900 \pm 600$ & Mammoth tooth & & \\
\hline \multirow[t]{5}{*}{ Pogon } & & $18690 \pm 770$ & LU361 & Mammoth tooth & Gribchenko, 2006; Gribchenko et al., 2011 \\
\hline & & $22300 \pm 500$ & GIN10193 & Bone & \\
\hline & & $22500 \pm 450$ & GIN10194 & Bone & \\
\hline & & $23800 \pm 700$ & GIN11315 & Bone & \\
\hline & & $24000 \pm 1200$ & GIN11312 & Bone & \\
\hline \multirow[t]{2}{*}{ Obollonia } & Boiler room & $15200 \pm 200$ & SPb442 & Mammoth bone & Stupak, 2011 \\
\hline & Excavation & $20730 \pm 120$ & Ox28035 & Mammoth bone & \\
\hline \multirow[t]{4}{*}{ Dorochivtsy III } & Layer 6 & $22300 \pm 100$ & GrXX & Charcoal & Koulakovska et al., 2011, 2015 \\
\hline & Layer 4 & $20976 \pm 76$ & KoXX & Charcoal & \\
\hline & Layer 3 & $20700 \pm 90$ & GrXX & Charcoal & \\
\hline & & $20504 \pm 83$ & KoXX & Charcoal & \\
\hline
\end{tabular}

A palynological study was conducted in Pushkari 1 by Velichko et al. (1999) in the cultural layer. It shows the predominance of herbaceous taxa. Velichko et al. (1999) noticed the presence of Plantago sp. (plantain) and Anthoceros sp. (hornwort) which are related to sp.) (Gribchenko, 2006). Yu.N. Gribchenko concludes to an open landscape of steppe-tundra type, with the proximity of forest cover.

These sites have yielded many lithic artefacts. The excavation VII of Pushkari 1 yielded about 20000 artefacts studied by V.I. Belyaeva 


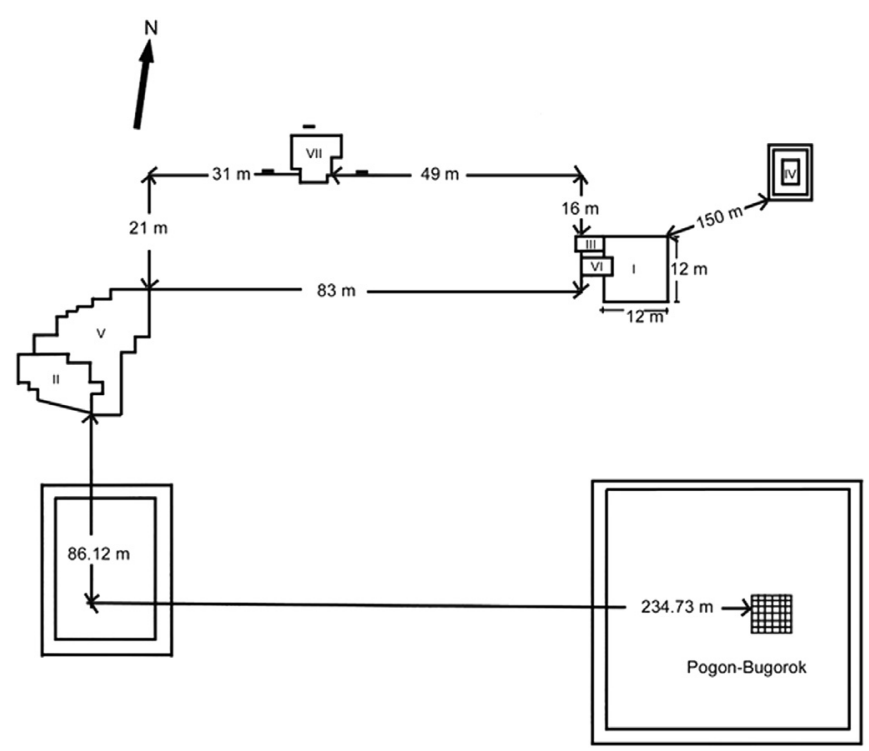

Fig. 3. Plan of excavation sectors at Pushkari 1 and Pogon (after Belyaeva, 2002, 2009).

(2004) and the excavation VII of Pogon furnished 2300 flint remains (Vasil'ev, 2014).

Both assemblages are similar. They present long, regular, retouched Most are symmetrical with oblique truncation and a backed edge. Some present bilateral distal retouches whereas others are asymmetric. Some points present lateral retouches and proximal truncation called Pushkarian points (Fig. 4). There are also side-scrapers and endscrapers, microliths and combined tools in low proportion. There are many flakes.

It is a complete lithic assemblage containing the products of debitage, and oriented on hunting activities. The lithic assemblage of Pushkari 1 is particular, presenting some "archaic" pieces and some Epigravettian features. It is classified as a particular facies of a recent Gravettian with Epigravettian features. The ancient Epigravettian features are defined by the microlithisation of the stone tools, the increase of laterally abrupt retouched tools, sometimes associated with artistic elements (for instance Kostienki 8/I, Kostienki 11/II, Kostienki 21/III, Ciuntu, Crasnaleuca-Stanişte/VII).

From the data about comparison with other cultural complexes (the Kostenki- Borshevo group, the Kostenki- Alexandrovka group, the Gagarinovo-Khotylevo group and the Kostenki- Avdeevo group (Amirkhanov, 1998)) Pushkari 1 and Pogon industries are distinguished from others (Rudinski, 1947; Boriskovski, 1953; Nuzhnyi, 1992, 2009; Belyaeva, 1997; 2000, 2002, 2004; Sinitsyn, 2007). From the excavations conducted by I.G. Shovkoplias (1967) and the new excavations lead by D.V. Stupak in 2002 and 2005, and lithic study conducted by D. Yu. Nuzhnyi (2009), only the site of Klussy, which presents a similar stratigraphic situation with Pushkari 1, showed the same lithic industry. Klussy is the only site which could related to Pushkari 1, forming a particular facies called Pushkarian.

The flint is black, coming from Cretaceous deposits accessible at the base of the promontory. At Pogon, P.M. Vasil'ev identified a few white elements which were imported.

The site of Pushkari 1 contains many bones of woolly mammoths. Our aim is to understand what are the characteristics related to the presence of these large mammals, taking in account other species. That is why it is necessary to assess the anatomical representation, to define the population structure, which can help us to understand their presence on the promontory. Taphonomic observations can also lead to an understanding of the preservation of the cultural layer. Considering these factors, the objective is to understand what could be potential interactions with human groups, whether this species played a role in terms of food and/or construction material by use of bones. We studied the material of the excavation number VII from 2003 to 2013 curated at the village of Pushkari (publication in process).

Concerning Pogon, the problem is quite similar. We studied the material of the excavation VII from 2011 to 2013. Bones are curated at the Museum of archaeology of Kiev.

\subsubsection{Obollonia}

At $100 \mathrm{~km}$ from the complex of Pushkari, near an ancient channel of the Desna river, the site of Obollonia was discovered in 2010 during civil engineering of a boiler room. The excavations led by D.V. Stupak were started in 2011.

The site of Obollonia is located east of a promontory formed by the Desna and its right tributary, the Bystrytsia river. The geological study was made by Yu. N. Gribchenko (Stupak et al., 2014) (Fig. 7). From the sedimentation of the layers, the cultural level was disturbed by movements due to water. Its situation corresponds to a cold period between 24 000-17 000 BP.

The site of Obollonia was dated on the one hand from a bone from the boiler room and on the other hand on a bone from the excavation. The first one is dated to $15200 \pm 200(\mathrm{SPb} 442)$ and the second is dated to $20730 \pm 120$ (Ox28035) (Stupak, 2011). However, the archaeological remains of the excavation and of the boiler room would be of the same geological layer (Stupak et al., 2014). The most recent date has been called into question and the new data about sedimentation tend to dismiss this date (Table 1).

The pollen analysis was conducted by Yu.M. Gribchenko (Stupak et al., 2014.). During the cultural occupation, there was a majority of shrubs and herbs. The identified plant species, Betula nana, B. fruticosa, Botrychium boreale, Selaginella selaginoides, Armeria sp.,

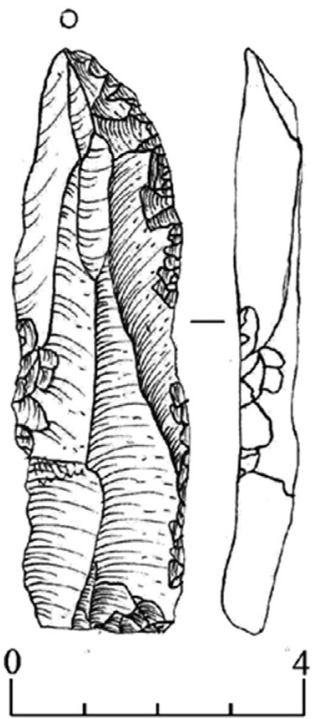

a)
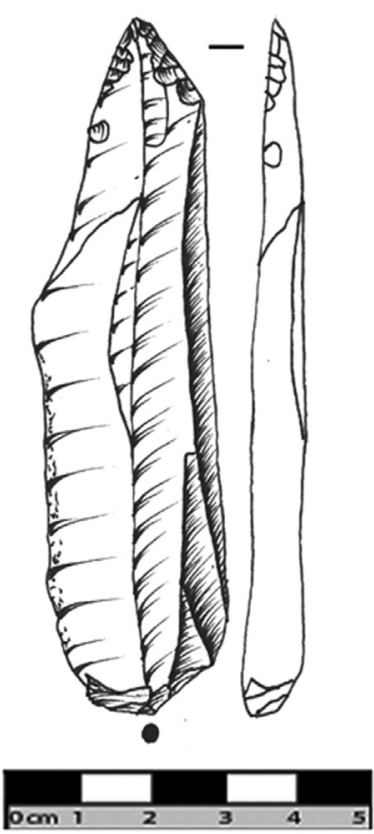

b)
Fig. 4. Pushkarian points with lateral retouches and proximal truncature. a) Pushkari 1 (Belyaeva, 2004); b) Pogon (Vasil'ev, 2014). 
Artemisia sp., correspond to a cold steppe environment. The presence of the algae Pediastrum sp. reflects a change in the course of the river.

The lithic remains were studied by Stupak (2010, 2011, 2012, 2013, 2014). There are 11553 remains (flint: 9548; quartzite: 2005). The cores were fully used. Tools are scrapers, burins and microliths. There are also particular pieces of flint industry, including Aurignacian burins (Fig. 5). This assemblage is defined as an Epiaurignacian.

The Epiaurignacian corresponds to the resurgence of similar techniques than the Aurignacian, notably by the presence of boathull-shaped burins and microliths, without direct affiliation. This phenomenon is observable in different sites (for instances Raskov VII and Climautsi II). According to many authors, it is an error to give a similar techno-typological denomination of these different complexes for which the comprehension remains difficult to understand (Covalenco, 2003-2004; Zwyns, 2004; Noiret, 2007; Chirica and Văleanu, 2007).

The flint which was used in Obollonia comes from Kanev and is predominantly local flint, about $30 \mathrm{~km}$ distant. The quartzite is local.

Obollonia is a new site in the Desna valley. Our aim is to determine the species, the taphonomical process to better understand the site conditions and the role of these faunas within human populations to define the cultural particularities. We studied bones curated in the village of Obollonia, from the emplacement of the boiler room and from the excavations from 2011 to 2013.

\subsection{Dniester valley}

\subsubsection{Dorochivtsy III}

A.P. Chernysh made surveys at Dorochivtsy located in Western Ukraine and discovered two palaeolithic sites in 1951: Dorochivtsy I (Gorbi) et Dorochivtsy II (Toloka) (Chernysh, 1954). Then, in 1968, he discovered a third station: Dorochivtsy III (Chernysh, 1985) which was only excavated in 2007 (Koulakovska et al., 2008).

The site of Dorochivtsy III contains seven archaeological layers refered to the Palaeolithic. The geological study was made by P. Haesaerts (Koulakovska et al., 2012). The cultural layers are in sandy loam deposits. Dorochivtsy III is located on external bank of a fluvial terrace. It has favorable conditions for the preservation of archaeological material. The increased presence of sand was observed in layer 6 . We observed cryoturbation between layers 3 and 4, 4 and 5, and 5 and 6 (Fig. 7).

Dates were obtained from three layers. Layer 6 was dated to $22300 \pm 100$ and the layers 4 and 3 to around $21000-20500 \mathrm{BP}$ (Koulakovska et al., 2011, 2015) (Table 1). According to N. Gerasimenko (in press), the archaeological layers of Dorochivtsy III are characterized by a steppe-tundra environment with the presence of forest corridors and hydrophilous species.

The lithic assemblages were studied by L. Koulakovska and V. I. Usik (Koulakovska et al., 2012). Layers 3-4-5 furnished Gravettian lithic assemblages.

From the works about Gravettian cultures, the sites of Dniester area do not contain Aurignacian tools or Mousterian artefacts (Kozlowski, 1986). Moreover shouldered points are narrow and almost unmarked. These characteristics differ from those of

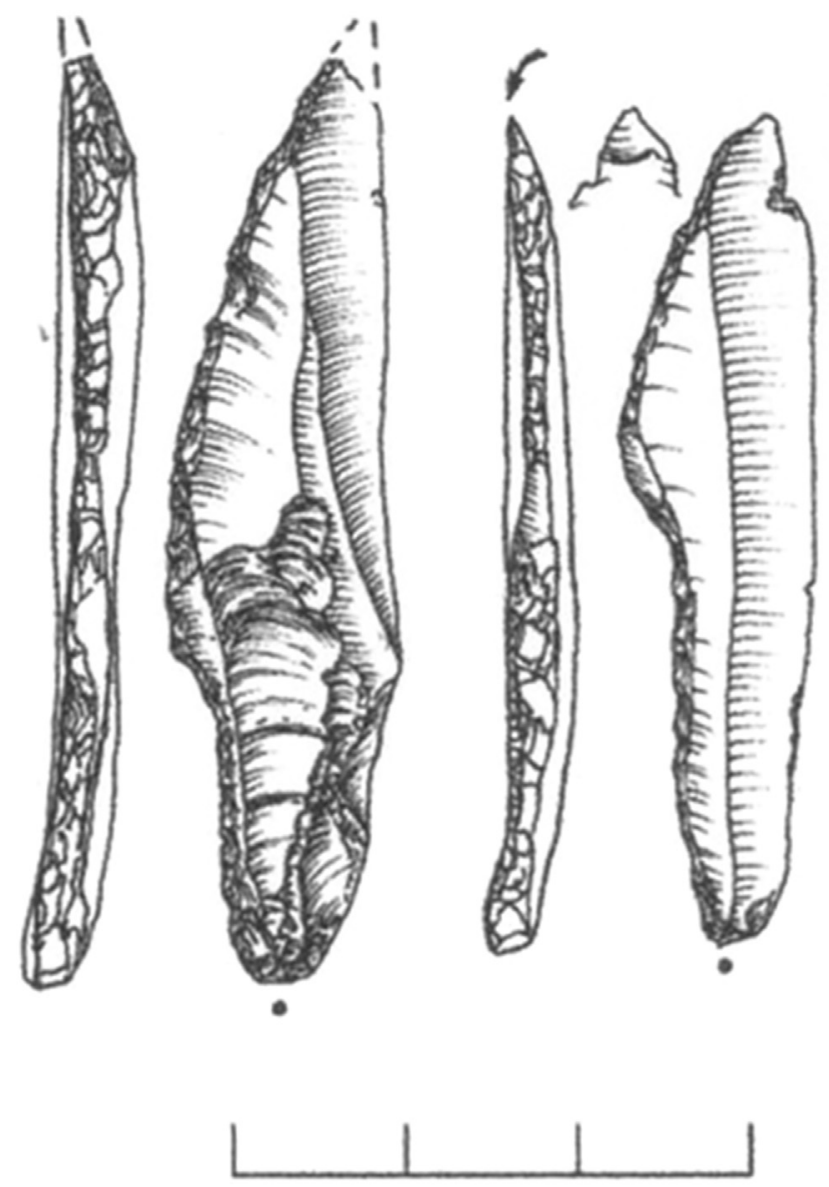

Fig. 6. Retouched bladelets of the layer 6, Dorochivtsy III (V. Usik In: Koulakovska et al., 2012).

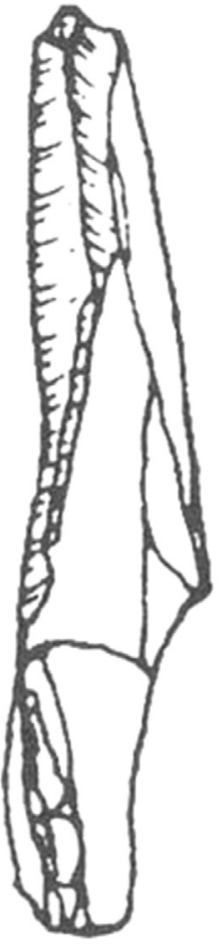

\section{$2 \mathrm{~cm}$

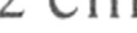

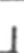




\section{Pushkari 1}

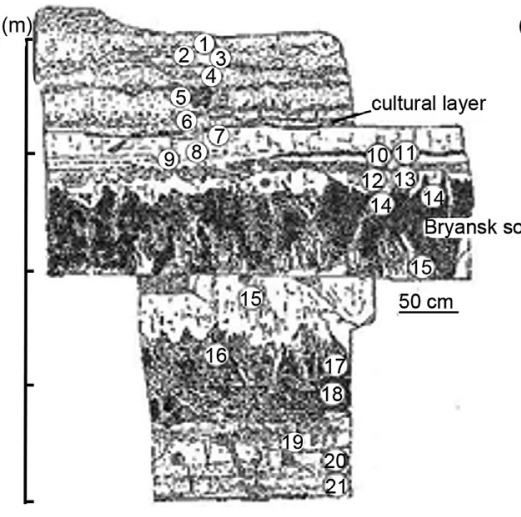

1: humus-bearing. Dark sandy clay. 2: sandy clay. Lenses of heterogeneous sands and dark brown sediments

3 : sands with calcareous sands and lithis artefacts in the lower part

4: sand, light brown fine grain and deep brown clays, with ferruginous concretions. 5. silty light brown sediments with thin incursions of dark brown carbonate sands. 6 : light brown sediments slightly oxidized (iron), covering the cultural layer. 7:

8. sandy loam, with gleyed sediments. 8. sandy loam, wh gleyed sediments. 10: prayish-brown clay. with gleyed sediments. 11: grayish-brown clay.

, light, dense, slightly gleying brown clay.

13: dense light brown clay, with greenish sediments.

14: dense silt disturbed by solifluction. 15: light gray silt with gleyed sediments 16: gray-brown silts.

17: dark gray silts with gleying lenses and concretions.

brown silt, and sand

19: sand, dense chalky yellow-brown silt and ortsand.

20: dense light and dark gray silty sands,

with ferruginous concretions.

21: light gray sands with traces of oxidation

and greenish sandy laoms.
Pogon

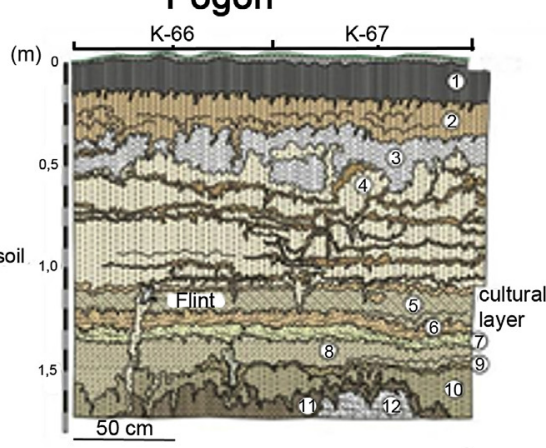

1: humus, modern soil. Heterogeneous gray sandy loam.

2: heterogeneous dense brown loam with gray sandy loam.

3 : heterogeneous light gray sandy loam.

4: ortsand. heterogeneous porous brownish gray loam with iron and manganese oxides. Cryogenic perturbations.

5: dense brownish gray loam with iron and manganese oxides and gley.

6: dense brownish gray loam.

7: heterogeneous light gray loam with iron and manganese oxides.

sand and humus. sandy loam with brown ortsand.

: dense brown loam.

10: brownish gray loam with iron and

mangann oxides and lenses of humus.

11. Bryansk

11: Bry

12: light gray loam with silty carbonates.

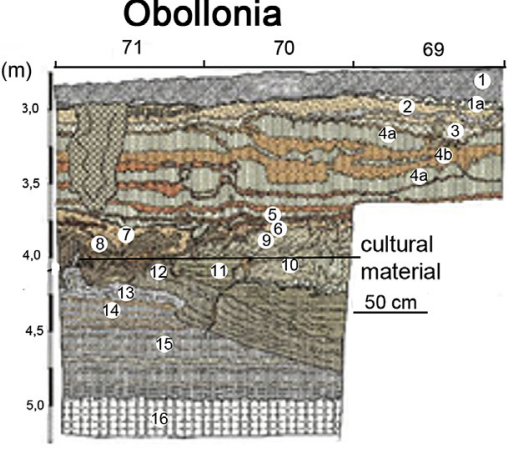

1: modern soil. sandy loam more homogeneous in $1 \mathrm{a}$.

2 : fine-grained dense brownish gray sand with some incursions of gray sand.

3 : dense light gray sandy loam.

4: ortsand. Aternation of coarse light

yellow-gray

silty sand (4a) and dark red-brown

ortsand (4b). Porous yellowish sand altrenating with

7: heterogeneous brownish gray loam.

8: dense sandy brownish gray loam

with cryogenic deformation and ortsand.

Cultural layer.

9: brownish gray sandy loam, with gray sand.

11: gray silty sand with lenses of black sand.

12: brownish gray sand.

13: deformed layer of light gray sand.

14: gray and brown slightly clayey sand sand.
Dorochivtsy III
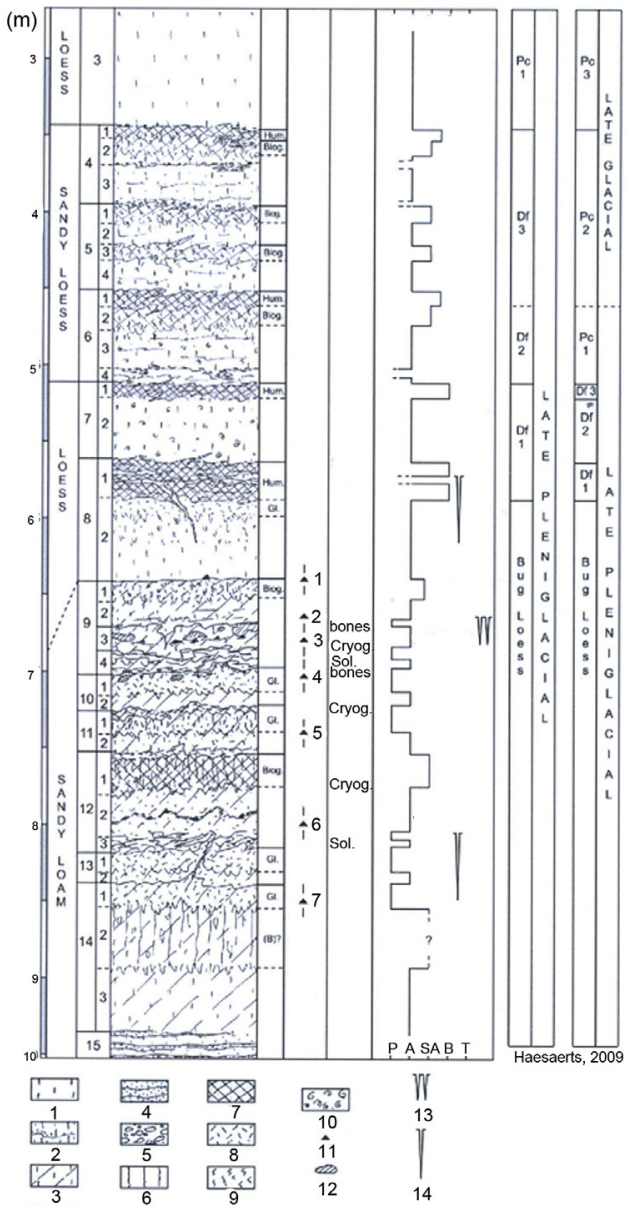

Hum: top soil ; Biog: biogaleries ; Sol: solifluction ; Cryo: cryoturbation

T: temperate ; B: boreal ; SA: sub-arctic ; A : arctic ; P: permafros.

1: loess ; 2 : sandy loam ; 3 : loess loam ; 4 : sand; 5 : gravel;

6: ocher clay; 7 : humus loam; 8 : gray sitt (tundra gley); 9 : biogaleries ;

10: molluscs ; 11: lithic artefacts ; 12 : bones ; 13 : frost crack ;

14: piece of ice. 
Pavlovian and Kostienkian cultures. That is an original culture of the Dniester valley called Molodovian or Eastern Gravettian (Boriskovski, 1953; Grigor'ev, 1970; Chernysh, 1973; Otte, 1981; Otte et al., 1996; Borziac and Koulakovska, 1998; Borziac and Chirica, 1999; Djindjian, 2002; Noiret, 2004, 2007; Nuzhnyi, 2009).

Layer 6 presents particular pieces as retouched bladelets (Fig. 6), different from those known in the region. This profile corresponds to an ancient Epigravettian. Dorochivtsy III is located in an area which corresponds to a narrow canyon containing lithic deposits. Owing to the fluvial erosion of the Cretaceous stratigraphic units, flint nodules were rolled. This flint of good quality was easy for human groups to reach. We know that the human groups from Dorochivtsy III directly used this local flint of good quality to make tools, left on the site.

The site of Dorochivtsy III is a newly discovered site in the Dniester valley. Zooarchaeological results were recently published (Demay et al., 2015). We studied the faunal material from 2007 to 2010 curated in the Archaeological Museum of Kiev. Our aim was to determine the species and the exploitation of fauna to clarify the activities of human groups. We wanted to compare the cultural process highlighted in this site with those of the Desna valley. Our aim is to determine the human involvement during the Upper Pleniglacial in the European eastern territory.

\section{Methods}

The study was undertaken following zooarchaeological methods including paleontology, taphonomy and palethnography (Poplin, 1976; Driesch, 1976; Binford, 1979; Barone, 1986; PatouMathis, 1994; Lyman, 1994, 2008; O'Connor, 2000; Péan and Patou-Mathis, 2003; Reitz and Wing, 2008). Taxonomic references and systematics were used in agreement with the code of zoological nomenclature (2000). To determine the faunal remains we used comparative anatomy books (Lavocat, 1966; Lessertisseur and Saban, 1967a,b; Pales and Lambert, 1971; Schmid, 1972; Olsen, 1979; Pales and Garcia, 1981; Barone, 1986; Hillson, 1986; Altuna, 2004), and osteological collections of references (Collections de l'Institut de Paléontologie Humaine - Muséum National d'Histoire Naturelle de Paris).

To determine age we used the tooth eruption and wear stages together with epiphysation stages of postcranial bones. Sex of individuals was determined from the sexual dimorphism in relation with osteometric and morphological differences. Concerning mammoth we used data and stages from Coppens (1965), Laws (1966), Roth (1984), Haynes (1991), Averianov (1996), Lister (1996), Shoshani and Tassy (1996), Beauval et al. (1998) and Lister (1999). Reindeers were studied from Bouchud (1953), Miller (1972, 1974), Hufthammer (1995), Enloe (1997) and Weinstock (2000). For horse, we used Barone (1986) and Eisenmann (1991). Measurements were taken from Driesch (1976), Agenbroad (1994) and Lister (1996).

Age classes of animals are determined as follows:

Mammuthus primigenius:

Juvenile: stages 0-IXa; from 0 to 8-12 years old.

Young adult: stages IXa-XVII; from 12 to $18-26$ years old.

Intermediate adult: stages XVII-XVIIIa; from 25 to 30 years old.

Mature adult: stages XVIIIa-XXVI; from 30 to 50 years old.

Old adult: stages XXVI-XXX death; from 50 to 60 years old.

Equus sp.:

Juvenile: from 0 to 2 years old.

Young adult: from 2 to 4 years old.

Intermediate adult: from 4 to 6 years old.

Mature adult: from 6 to 18 years old.

Old adult: from 18 to 25 years old.
Rangifer tarandus:

Juvenile: from 0 to 2 years old.

Young adult: from 2 to 3 years old.

Intermediate adult: from 3 to 5 years old.

Mature adult: from 5 to 10 years old.

Old adult: from 10 to 15 years old.

Season at birth, along with age determination, can inform us about season of kill and human occupation. The works carried out carcasses of juvenile mammoth found in Siberian permafrost indicate that the births of mammoths probably took place during spring (Rountrey et al., 2012). Non-shed antlers and birth seasonality of reindeers provide more information about seasonal slaughter and human occupations (Bouchud, 1954; Murray, 1993; Lincoln, Tyler, 1994) (Fig. 8).

We used quantitative units from Poplin (1976) and Lyman (2008). Abbreviations correspond to:

NR: Number of remains.

NRt: total Number of Remains.

MNE: Minimum Number of element. It defines the representation of skeletal elements preserved for a taxon, taking into account the reassemblies, pairings, age and sex.

cMNI: Minimum Number of Individuals by combination, taking into account the reassemblies, pairings, age and sex.

Ind: Indeterminate.

Ps: percentage survivorship. It establishes an observation on three levels: for each element; for each anatomical region; for the overall deficit (total) of the species It is calculated by element. It takes into account the MAU (Minimum Animal Unit) which is based on the minimum number of individuals evaluated by the cMNI.

$\mathrm{Ps}=\mathrm{MNE} \times 100 / \mathrm{Qsp} \times \mathrm{MNI} \max =\mathrm{MAU} \times 100 / \mathrm{MNI} \max$

\section{Zooarchaeological study}

\subsection{The Desna valley}

The Desna valley is known as the place of use of mammoth bones as building material and industry and artistic support during the gravettian and epigravettian periods. Combining the data (Soffer, 1985), the faunal remains delivered by gravettian sites

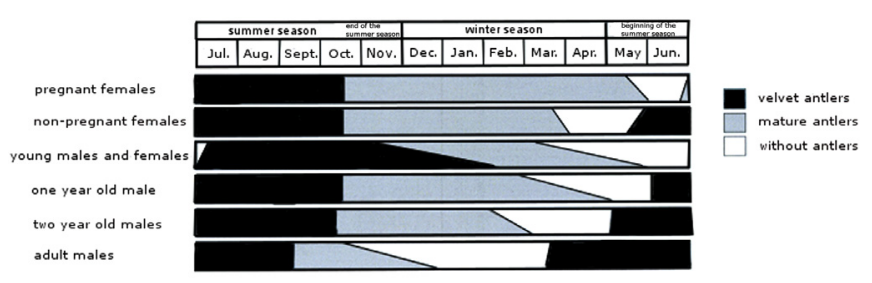

a)

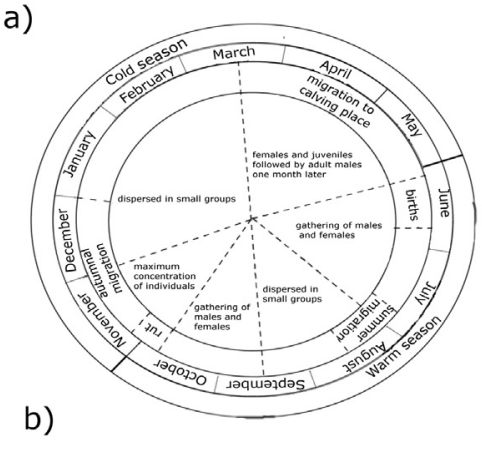

Fig. 8. Information about reindeer. a) seasonal cycle of reindeer antlers (from Murray, 1993); b) annual cycle of reindeer herds (from Kuntz, 2011). 
(Khotylevo II, Berdyzh, Yurovichi) are composed of mammoth, horse, rhinoceros and aurochs, also wolf, fox and bear. The epigravettian sites (Mezhirich, Mezin, Yudinovo, Gontsy, Eliseevichi 1, Suponevo, Timonovka I, Dobranichevka, Fastov) furnished mainly remains of mammoth, horse, reindeer, rhinoceros, bison, red deer, megaceros, boar, wolf, fox and bear. Activities and faunal exploitation are more diversified during the epigravettian period. The period between 23 and $16000 \mathrm{BP}$ is poorly known. The sites of Pushkari 1, Pogon and Obollonia are the rare sites presenting human occupations in the Desna valley between 23 and 20000 BP.

\subsubsection{Global quantification}

Concerning Pushkari 1, Pogon and Obollonia, the faunal spectrum is relatively restricted with a low density of bone remains. Fox is represented in all sites, with other carnivores as C. lupus in Pushkari and Pogon and as U. arctos in Obollonia. Perissodactyls and artiodactyls are represented in low proportion and mammoth is the most represented (Table 2; Table 3; Table 4). The proportion of the different species is quite similar in Pushkari 1 and Pogon. Concerning Obollonia there are only carnivores and mammoth.

Table 2

Counting of the faunal remains, Pushkari 1 - excavation VII.

\begin{tabular}{lrrr}
\hline Species & NR & MNE & cMNI \\
\hline Mammuthus primigenius & 419 & 168 & 11 \\
Equus sp. & 12 & 8 & 1 \\
Rangifer tarandus & 6 & 4 & 1 \\
Canis lupus & 22 & 22 & 1 \\
Vulpinae & 115 & 84 & 3 \\
Sub-total & $\mathbf{5 7 4}$ & $\mathbf{2 8 6}$ & \\
Large mammal & 169 & 12 & \\
Large/medium sized mammal & 14 & 1 & \\
Medium sized mammal & 41 & 12 & \\
Small sized mammal & 25 & 9 & \\
Indeterminate & 50 & & $\mathbf{1 7}$ \\
Total & $\mathbf{8 7 3}$ & $\mathbf{3 2 0}$ & \\
\hline
\end{tabular}

Table 3

Counting of the faunal remains, Pogon - excavation VII

\begin{tabular}{lrrl}
\hline Species & NR & MNE & cMNI \\
\hline Mammuthus primigenius & 63 & 18 & 2 \\
Equus sp. & 15 & 10 & 1 \\
Cervidae (cf. Rangifer tarandus) & 7 & 5 & 1 \\
Canis lupus & 1 & 1 & 1 \\
Vulpinae & 62 & 57 & 3 \\
$\quad$ Indetermined & 49 & 44 & 1 \\
V. vulpes & 7 & 7 & 1 \\
A.lagopus & 6 & 6 & 1 \\
Sub-total & $\mathbf{1 4 8}$ & $\mathbf{9 1}$ & \\
Large mammal & 223 & & \\
Indeterminate & 1199 & & \\
Total & $\mathbf{1 5 7 0}$ & $\mathbf{9 1}$ & $\mathbf{8}$ \\
\hline
\end{tabular}

Table 4

Counting of the faunal remains, Obollonia.

\begin{tabular}{lrrl}
\hline Species & NR & MNE & cMNI \\
\hline Boiler room 2010 & & & 3 \\
Mammuthus primigenius & 44 & 25 & 1 \\
Vulpes vulpes & 18 & 18 & \\
Indeterminate & 10 & & $\mathbf{4}$ \\
Total & $\mathbf{7 2}$ & $\mathbf{4 3}$ & 3 \\
Excavation 2011-2013 & & & 1 \\
Mammuthus primigenius & 231 & 22 & 1 \\
Vulpinae & 6 & 5 & \\
Ursus arctos & 1 & 1 & \\
Large mammal & 8 & & \\
Medium sized mammal & 83 & 8 & $\mathbf{5}$ \\
Small sized mammal & 5 & 4 & \\
Indeterminate & 453 & $\mathbf{4 0}$ & \\
Total & $\mathbf{7 8 7}$ & & \\
\hline
\end{tabular}

\subsubsection{Taphonomical processes}

In Pushkari and Pogon, the surfaces of bones are altered and bones are pulverulent or concretioned, needing a study directly on the excavations concerning the method of consolidation. The bones were covered by loess sediments, whose acidity is probably the origin of the intense alteration of the bones. In Obollonia, bones show better preservation, with well-preserved surfaces.

In the three sites, bones are fragmented, in particular mammoth bones, mainly cranial and axial skeletons. It seems to indicate natural processes and destruction of bones because their morphologies are more brittle.

In Pushkari 1 around half of the remains, especially large mammals, present rough surfaces and large detachments of splinters due to weathering. Mammoth bones have long been exposed to the open air, probably due to their large size. The oxide deposits (manganese and iron), due to water percolation are visible on many bones of large, medium and small mammals. There are few pits of dissolution due to runoff of water and acidic solutions generated by the installation of a vegetative cover later. The geological study indicated that the layer that covered the cultural layer has oxidized sediments (Velichko et al., 1997, 1999). This feature helps to explain the oxidation of bone remains by percolating water. There are around a quarter of bone remains affected by traces of charriage-à-sec, reflecting some soil movements and f trampling, but not really intense. The types of fractures observed on the bones of large mammals and medium-sized mammals are longitudinal cracks, spiral and stepped. Several bones have both fractures in nonhuman spirals and echelons. These phenomena are due to ice crystallization, drying and wetting. In Pogon, the situation is quite similar (Fig. 9).

In Obollonia, we observed the same phenomena of alteration on bone remains in both locci. Bone remains are affected by weathering. Some bones of mammoths are affected by runoff water. All the bones are damaged by oxidation phenomena due to water percolation (Fig. 20). Many bones are affected by alterations due to charriage-à-sec (Fig. 9).

In Pushkari 1 and Pogon, vermiculations due to the roots of the plants are concentrated in small areas of the bones of all species. These observations show a relatively poor vegetation cover on the promontory.

In Obollonia, more than half of the bones are affected by plant root marks. There are few marks of carnivores or rodents. A rib of a large mammal shows gnawing marks due to a small rodent. A distal epiphysis of humerus of a young adult mammoth and a rib presents gnawing marks due to a medium sized carnivore (Fig. 9).

In Pushkari 1, the taphonomic study suggests that bones were affected by freeze-thaw actions. Some bones of mammoths lay in open-air longer than others, buried more quickly. They were intensively damaged by acid sandy deposits. Carnivores are not responsible agents for the modification and accumulation of the assemblage. Then, after burial, alteration on bone surfaces implies a more humid climate than expected. Moreover, bones of the upper and lower extremities of canids are well preserved more or less in their anatomical position, indicating that bone deposits were little disturbed.

In Obollonia, according to the taphonomic study, we observe that bones were quickly buried in a wetland in the subsurface and subjected to some movement of sediments. The geological data (Stupak et al., 2014) testify to the existence of an ancient channel of the Desna river. During the warm season the melting ice probably caused flooding which could affect this bone assemblage. The presence of small bones can be explained by a low flow of the water or by their trapping within the larger bones. 

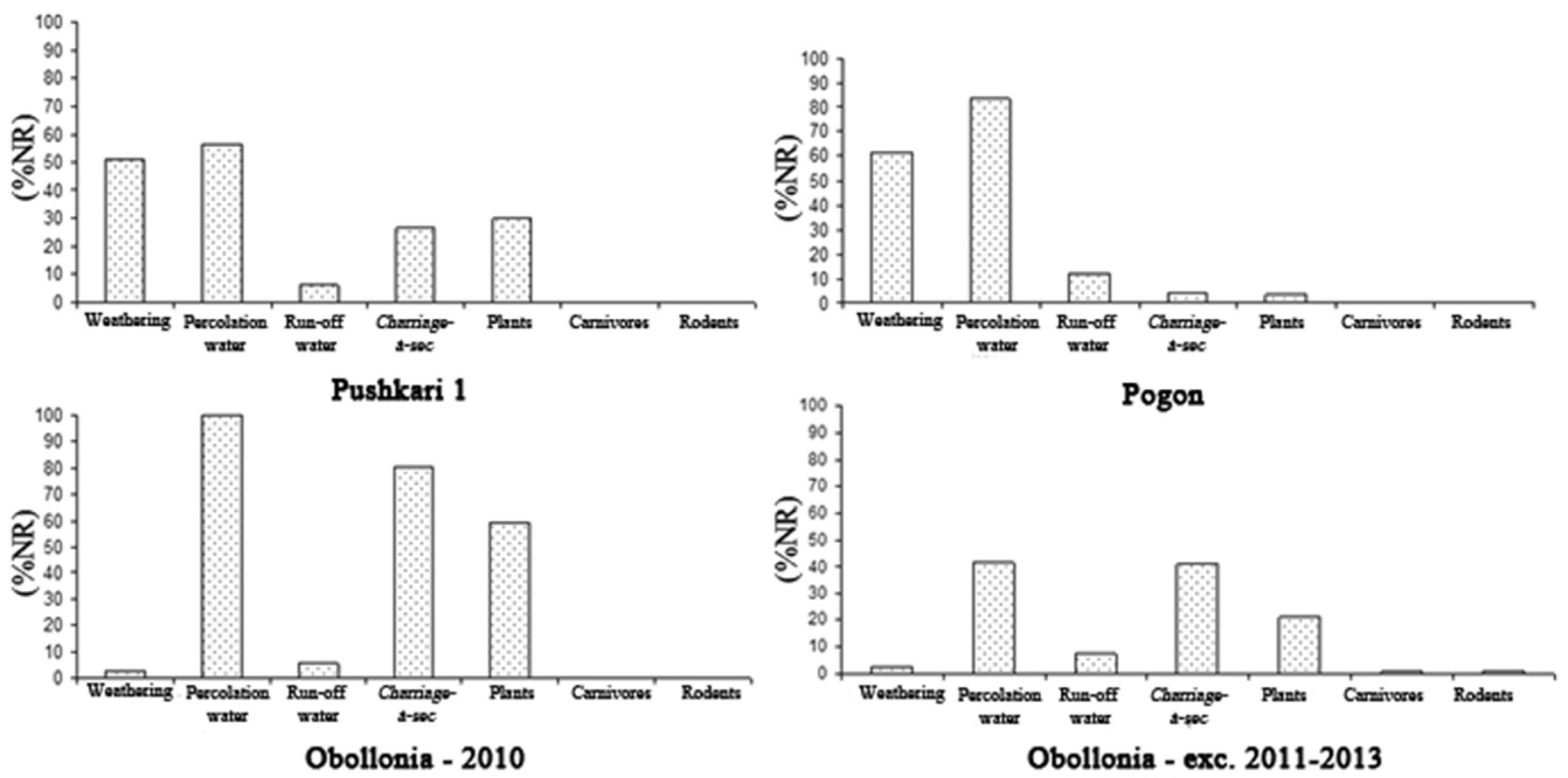

Fig. 9. Alterations due to climate-edaphic and non-anthropogenic biological agents of Pushkari 1-exc. VII, Pogon-exc.VII and Obollonia.

\subsubsection{Acquisition and treatment of fauna}

Mammoth is the most represented taxa, relatively common in the Gravettian and Epigravettian sites of the region. We want to determine the modalities of acquisition and exploitation of this animal by the different human groups and its place in the activities, taking into account the other species.

In Pushkari 1-exc. VII, we highlighted the presence of at least11 mammoths, two juveniles, two young adults, and seven intermediate or mature adults, with a male and a female. All skeletal elements are represented (Demay et al., 2016) (Fig. 10).

In Pogon, regarding skeletal preservation, mammoths is represented by few elements (18), skull fragments, three cheek (one deciduous tooth and two molars), and fourteen bones, all belonging to a sub-adult, two defenses, four ribs, six long bones (humerus, radius a, two femurs, two long bones indeterminate), an undetermined flat bone (scapula and coxal) and tarsal (cuboid). Based on the cheek teeth, the age of the mammoths corresponds to a juvenile and sub-adult. All major anatomical parts are represented.

In Pushkari 1, mammoths died nearby. In Pogon, the small number of remains does not allow a definite conclusion, but compared to skeletal conservation, it is conceivable that these mammoths also died nearby.

In Pushkari 1, we highlighted (Demay et al., 2016) that mammoth died on the promontory. The mortality profile of the excavation VII (Fig. 10) enhanced by the data of other loci (Rudinski, 1947; Boriskovski, 1949, 1953; Sablin, 1997), corresponds to the type C (adult dominant) (Haynes, 1987). This is typical of a hunted population. Combined with the lithic data, we propose that the promontory where Pushkari 1 is, was probably a favoured place for mammoth herds for particular food consumption (plants, minerals). Human groups had the opportunity to hunt them and to eat them. Moreover several vertebrae are articulated; they could correspond to an area of butchering.
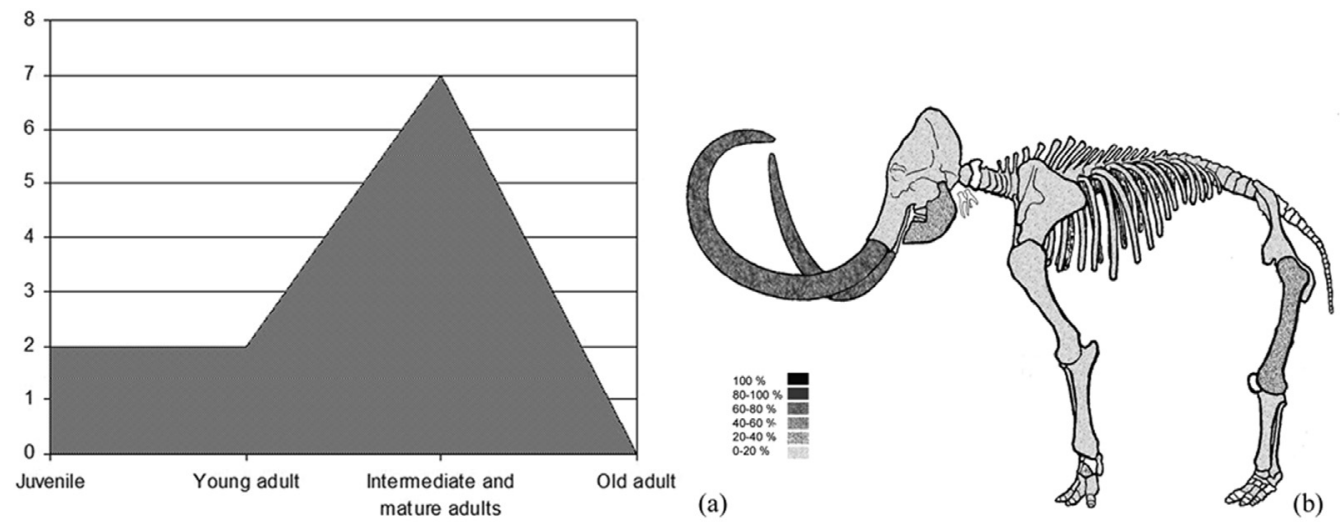

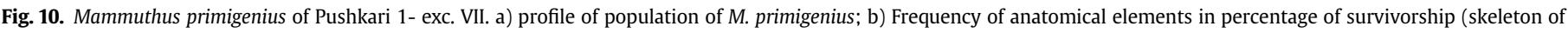
Borna modified from Abel 1925 in Osborn 1842). 
In Pogon the role of mammoths within the human strategies is quite difficult to determine. However, according to the taphonomic data, the skeletal preservation and the lithic industry, we can suggest similar activities with Puhskari I.

In Obollonia, concerning the remains of the boiler room, the woolly mammoth is represented by three individuals. Two individuals are represented by cranial bones (fragments of skull, teeth, a tusk and fragment of tusk), vertebrae (a thoracic vertebra and two lumbar vertebrae), three ribs (two left ribs and a right rib), scapular belt (a right scapula) and pelvic girdle (left and right pelvic bones), long bones (a right humerus, a fragment of radius, a right femur, a fragment of left tibia, a fragment of proximal extremity of right tibia), short bones (a left lunatum and a left triquetrum, a right triquetrum, a right hamatum, a left patella and a right navicular). The maximum diameter of the tusk is $220 \mathrm{~mm}$. The diameter of the tusks of young mammoths is less than $200 \mathrm{~mm}$. The diameter of the tusks of the females is between 200 and $350 \mathrm{~mm}$ (Haynes, 1991). So this tusk is from a young male, an adult female or an adult male. The diameter of the glenoidal cavity of the scapula is $150 \mathrm{~mm}$. The diameter of the glenoidal cavity of male and female mammoths is between 150 and $200 \mathrm{~mm}$; the largest diameters are generally attributed to males (Beauval et al., 1998). So this scapula is from a young individual, perhaps a female. Both extremities of a small sized humerus is not epiphysed, so this individual is less than stage XVIa (around 18-26 years old). The distal extremity of a tibia is not epiphysed, so this individual is less than stage XVIa (around 18-26 years old). The distal extremity of a femur is epiphysed, so this individual is more than stage XVIa (around 18-26 years old). The femur is normally epiphysised before the humerus, so this individual is older than the one we described before. Pelvic bones are quite complete. The height of ilium neck is $120 \mathrm{~mm}$. Compared with other bones, it cannot be a male. From the moment a male is twelve years old, the height of ilium reaches $160 \mathrm{~mm}$. So, this is a young female. From these data we determined at least two individuals, a young female and a mature small individual.

A juvenile is represented by three bones, a right scapula and left humerus and ulna (Fig. 11). The sizes of these bones (humerus: $13 \mathrm{~cm}$; ulna: $15 \mathrm{~cm}$ ) are less to those known about juvenile specimens (Fisher et al., 2012). This individual is a newborn or a foetus at term. The establishment of a female associated to this juvenile could suggest this was a female with a newborn or a gravid female.

Concerning the excavation 2011-2013, bones of mammoths belong to three individuals. Two of them are represented by cranial bones (fragments of skull, tooth and tusk), three thoracic vertebra, four ribs (two left ribs and two right ribs), a pelvic bone, a left humerus, a left ulna, a right radius a fragment of femur and a distal phalanx.

Considering a non-epiphysed distal epiphysis of a humerus, we determined that an individual is less than stage XVIa (around 18-26 years old). Considering an epiphysed proximal extremity of an ulna, another individual is older than the first one (more than stage XVIa, around 18-26 years old, if this is a female, more than stage XVIIIa-XX, around 25-35 years old, if this is a male). We have a young adult and a mature adult.

A juvenile is represented by a thoracic vertebra, two ribs (a left rib and a right rib) and right coupled ulna and radius (Fig. 11). According to the available measurement data, the size of the ulna of the juvenile of Obollonia $(21 \mathrm{~cm})$ is similar to those of Lyuba and Khroma (Fisher et al., 2012). This individual is probably 1-3 months old.

These bones cannot be assimilated with those of the juvenile of the boiler room. Assuming that the bones of the boiler room and those of the excavation could be related, we would have at least two newborns, two young adults and one mature adult.

In Obollonia, bones of mammoths present butchering marks. A rib bears anthropogenic cutmarks relied to defleshing (Fig. 12). Two
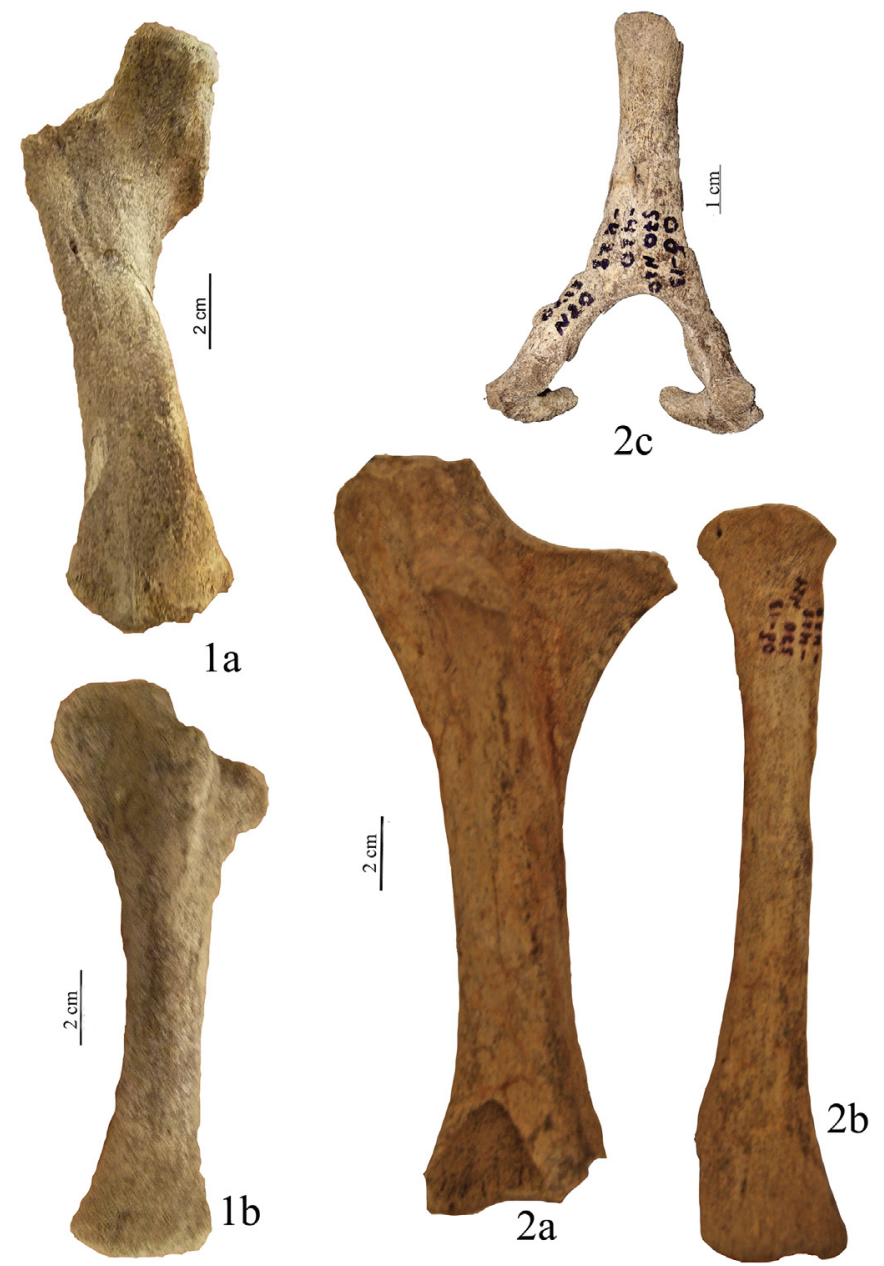

Fig. 11. Bones of juvenile mammoths, Obollonia. 1: boiler room 2010; a: left humerus in posterior view; b: left ulna in medial view; 2: excavation 2011-2013; a: right ulna in lateral view; b: right radius in lateral view; c: thoracic vertebra in anterior view. (ph: L. Demay).

fragments of long bone bear anthropogenic percussion marks. Although bones of mammoths do not contain marrow, it can be consumed (Fladerer et al., 2015). The observations of anthropogenic marks show the consumption of meat and marrow of mammoth. Human group(s) could have hunted these mammoths or could have scavenged fresh carcasses.

Pushkari 1 presents several thousand burned bone fragments. They consist of fragments of long bones of medium sized mammals and fragments of long bones and ribs of mammoth.

Pogon presents 1367 burned bone remains. They consist of fragments of bones of large mammals and of ribs of mammoths.

Obollonia exc. 2011-2013 presents 443 burned bone remains. They consist of fragments of long bones of medium sized mammals and fragments of long bones and ribs of mammoth.

In Pushkari 1-exc. VII, and other loci, the high representation of tusks raised questions. According to the general indexes of conservation, this is not a differential preservation, but a voluntary conservation of dental elements, particularly tusks. It is possible that the humans have stored them (Fig. 22). We are currently unable to define the possible secondary use. Although the cultural features are different between both sites, Kostienki 1 also showed a storage of tusks (Sinitsyn, 2007).

In Pogon, four small shallow pits were discovered (Fig. 13). Pits $\mathrm{n}^{\circ} 1,2$ and 4 are almost empty and contain only small fragments of 


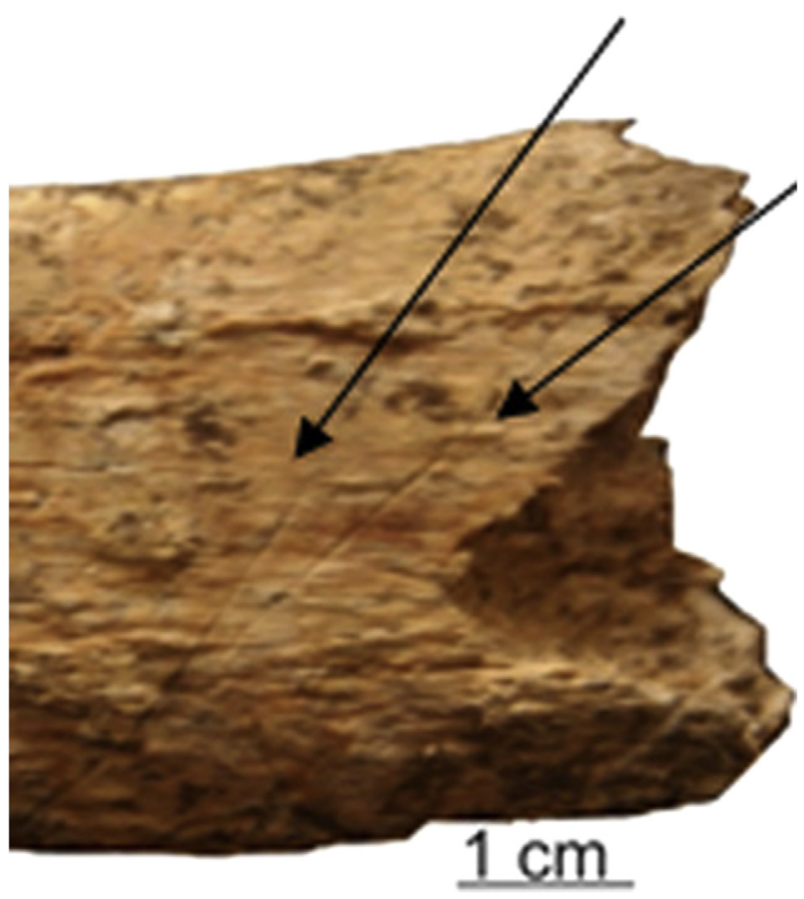

Fig. 12. Cutmarks on mammoth rib, Obollonia-exc. 2011-2013.

bones. Within the pit $n^{\circ} 3$, we noticed the presence of most remains as vertebrae of fox, fragmented bones, burned bones and the distal end of humerus of mammoth and a rib which presents an anthropogenic fracture by pressure characterized by a splinter of removal and put vertically (Fig. 14). These pits are near ashes which probably correspond to a fireplace.

In the Desna valley, the Gravettian site of Khotylevo II showed small pits with anthropogenic fractured ribs of mammoth aligned vertically, associated with ashes and fire places (Velichko et al., 1981) (Fig. 15). We can envisage in Pogon these pits correspond to holes to maintain a light structure above the fireplace, and some bones whose rib have been used as elements of dunning.

The site of Obollonia-exc. 2011-2013 furnished two ivory points (Fig. 16). One of them is $53 \mathrm{~mm}$ long with a diameter of $13 \mathrm{~mm}$. The other one is $22 \mathrm{~mm}$ long with a diameter of $11 \mathrm{~mm}$. They have the particularity to bear grooves as the "Isturitz type" (PyrénéesAtlantiques, France). This type of ivory points is new evidence of the behavioral activities in Eastern Europe.

The site of Obollonia - boiler room 2010 furnished a tusk of mammoth with engravings (Stupak, 2011) (Fig. 17). The length is $55.50 \mathrm{~cm}$, the maximum diameter of the proximal portion is $6.6 \mathrm{~cm}$. The diameter of the middle portion is $5.5 \mathrm{~cm}$. Although the tusk is incomplete, the proximal circumference is around $210 \mathrm{~mm}$ which indicates a young adult or adult male or female (from Haynes, 1991). The tusk was cut by transversal notch and then broken off completely. According to comments made by among others, Mr. Stupak and G. Klopatchev the surface has been prepared before being used. The study identified several distinct engravings composed of stylized figurative motifs as an anthropomorphic figure interpreted as a female, a snake incision, notches and chevron patterns. They were made with different flint or quartzite burins.

This type of artifact is totally new for this period in this area. The artistic style resembles the tusk of Kirillovska (Khvoika, 1913). The abstract rounded and shaded patterns are quite similar (Fig. 18). Kirillovska was uncertainly dated to $19200 \pm 250$ BP. New studies are in progress about this site.

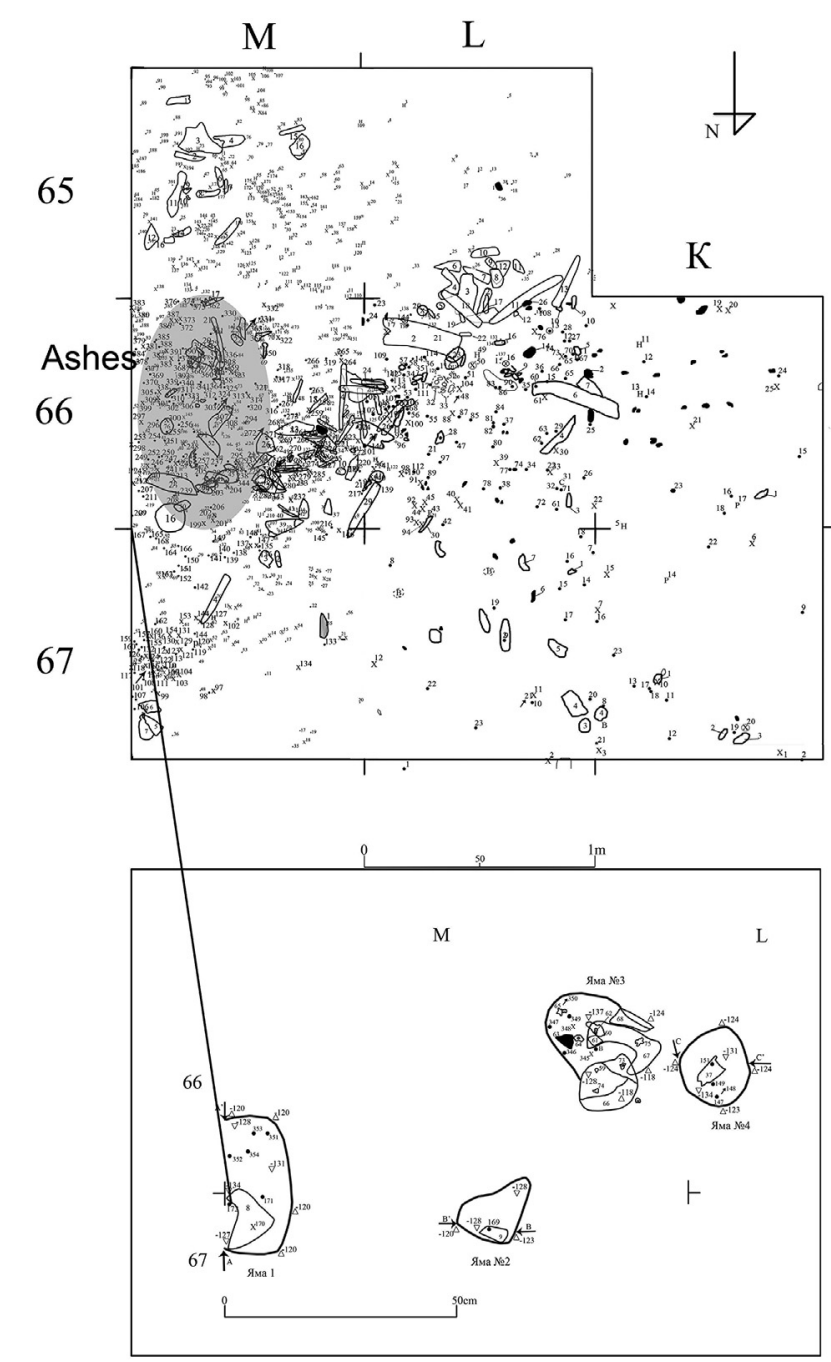

Fig. 13. Spatial distribution of Pogon and detail on the pits. (P. Vasil'ev).

We have few elements to determine precisely the seasonal settlements of human groups in Pushkari 1 and Pogon. However, the high number of mammoths on the promontory could be explained by the fact that at the end of the winter season, mammoths, stressed from lack of food, came to find the necessary nutriments. It is then possible that the herds of mammoths may go north to the end of the winter season-the beginning of the summer season and that human groups have exploited this opportunity to hunt.

In Obollonia, we highlighted the presence of foetus or new born mammoths. Within today's populations of elephants, births take place during unpredictable periods. However, it is plausible because of the cold climate during the ice age, that a season of birth propitious for survival of newborns existed within populations of mammoths. Supposing these data could be applied to all mammoths, the individuals of Obollonia could have died during the spring or beginning of summer. So if human groups ate these mammoth, they probably came during this period.

Vulpinae (Alopex lagopus - polar fox, Vulpes vulpes - red fox) are present in the three sites. In Pushkari 1, foxes are represented by 115 bone remains corresponding to at least 84 elements belong to at least three individuals. Considering the skeletal preservation in terms of percentage survivorship, all parts are represented, in particular cranial and limbs elements (Fig. 19).

In Pogon foxes are represented by 62 bone remains corresponding to at least 57 elements belong to at least three individuals. 

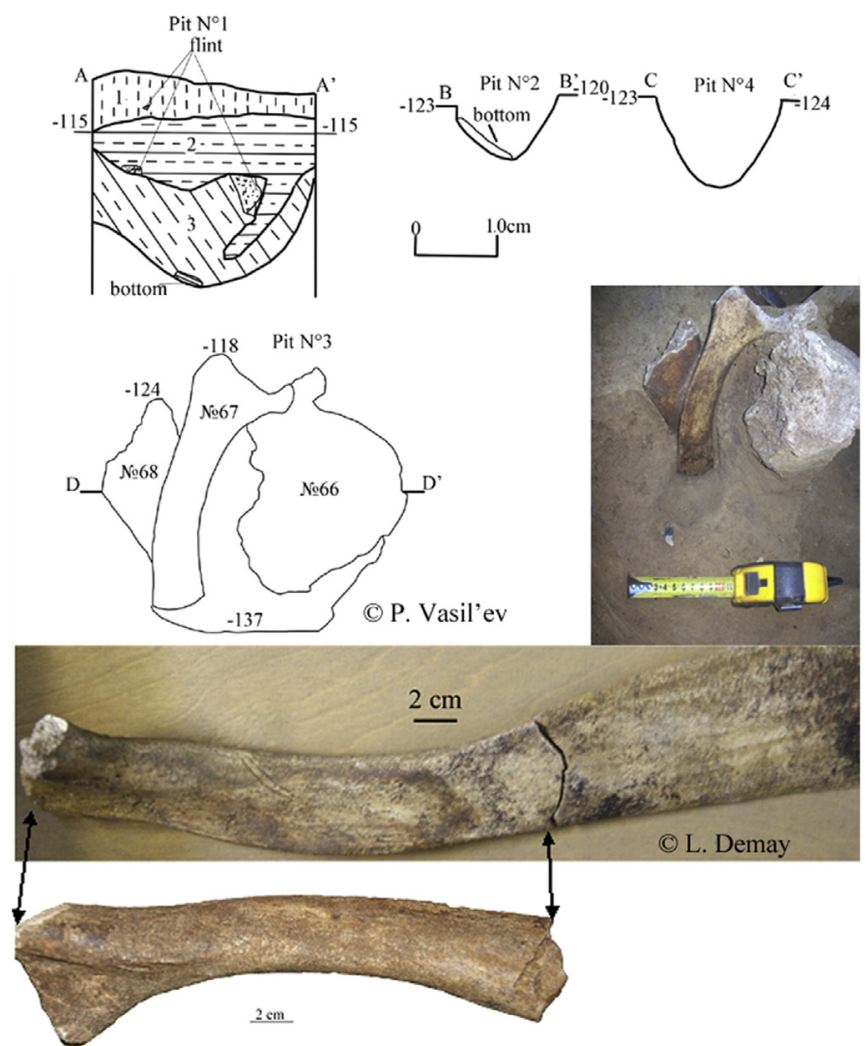

Fig. 14. Pit $n^{\circ} 3$ of Pogon with an anthropogenic fractured rib of mammoth, put vertically.
Elements are represented by three mandibles with teeth, a skull with maxillary and teeth, seventeen long bones (four humerus, a radius, four femur, five tibias and at least three indeterminate long bones), bones of the axial skeleton (vertebrae: eight lumbar vertebrae, two thoracic vertebrae, a caudal vertebrae and a rib), a calcaneum and a phalanx. As for Pushkari 1, considering the skeletal preservation in terms of percentage survivorship all parts are represented, in particular cranial and limb elements (Fig. 19).

Concerning fox in Pushkari 1 and Pogon, the skeletal preservation (Fig. 19) showed that these animals were brought complete on the site. Moreover in Pushkari 1 these bones are located in small pits in particular end limbs (Fig. 22). So, fox and perhaps wolf were killed and exploited for their fur.

In Obollonia, in the place of the boiler room, fox is represented by 18 bone remains corresponding to at least 18 elements belonging to at least one individual. The remains of fox are represented by cranial bones: a right maxillar with teeth $\left(\mathrm{P}^{1} ; \mathrm{P}^{2} ; \mathrm{P}^{3} ; \mathrm{P}^{4}\right.$; $\left.\mathrm{M}^{1} ; \mathrm{M}^{2}\right)$, a left mandibula with teeth $\left(\mathrm{P}_{2} ; \mathrm{M}_{1} ; \mathrm{M}_{2}\right)$ and a right mandibula with teeth $\left(\mathrm{P}_{1} ; \mathrm{P}_{2} ; \mathrm{P}_{3} ; \mathrm{P}_{4} ; \mathrm{M}_{1} ; \mathrm{M}_{2}\right)$. We measured the maxillar of fox (Table 5). Comparing with the data (Altuna, 2004), this individual is Vulpes vulpes. Morphometric data of mandibles cannot be exploited, but they couple with the maxillar.

Table 5

Measurements of maxillar of fox of Obollonia 2010

\begin{tabular}{ll}
\hline Criterion & Measurements $(\mathrm{mm})$ \\
\hline Length from $\mathrm{P}^{1}$ to $\mathrm{M}^{2}$ & 52 \\
Length $\mathrm{P}^{4}$ & 18 \\
Length $\mathrm{M}^{1}+\mathrm{M}^{2}$ & 22 \\
Length $\mathrm{M}^{1}$ & 11 \\
Width $\mathrm{M}^{1}$ & 12 \\
\hline
\end{tabular}
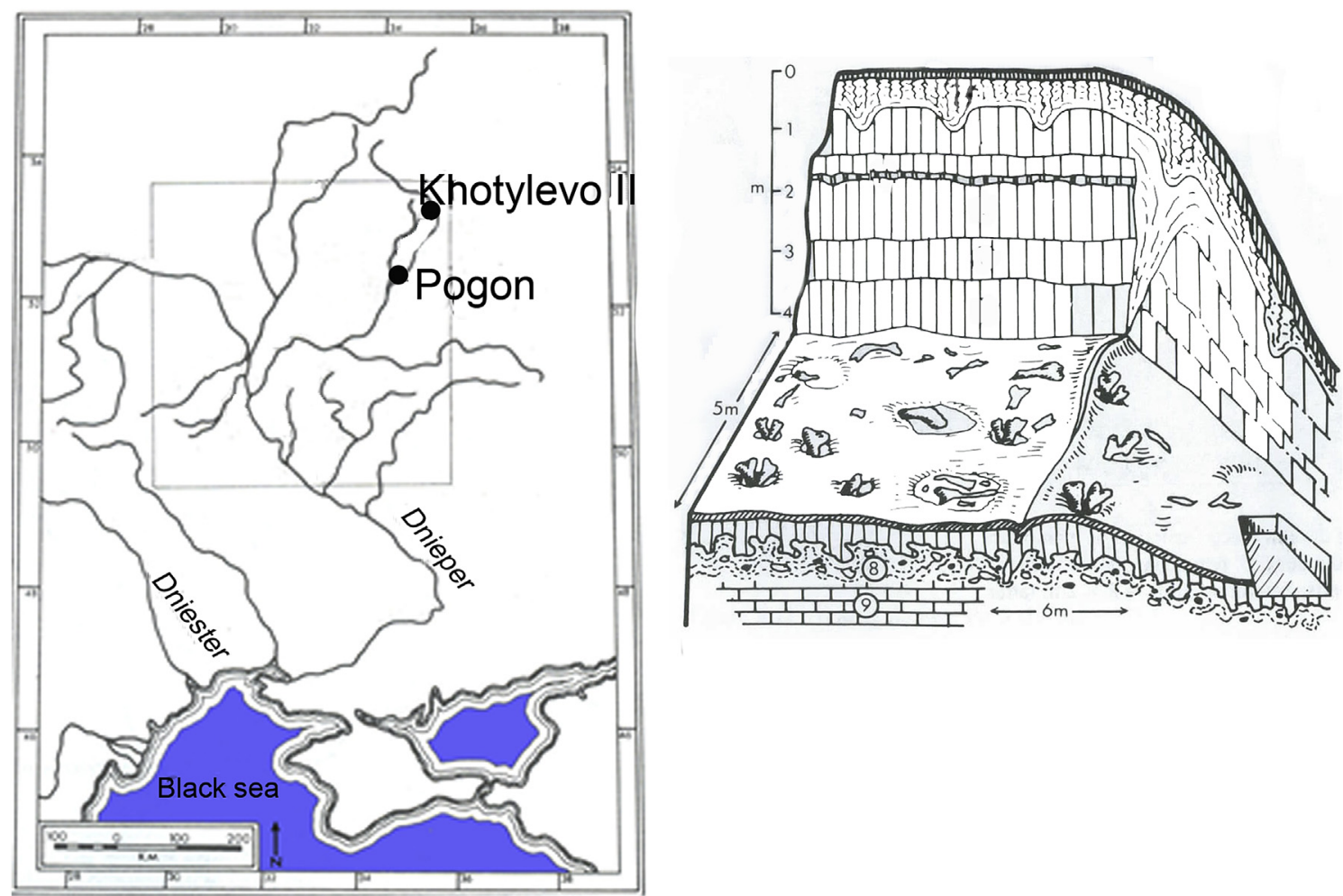

Fig. 15. Small pits with fractured mammoth ribs of Khotylevo II (after Velichko et al., 1981). 

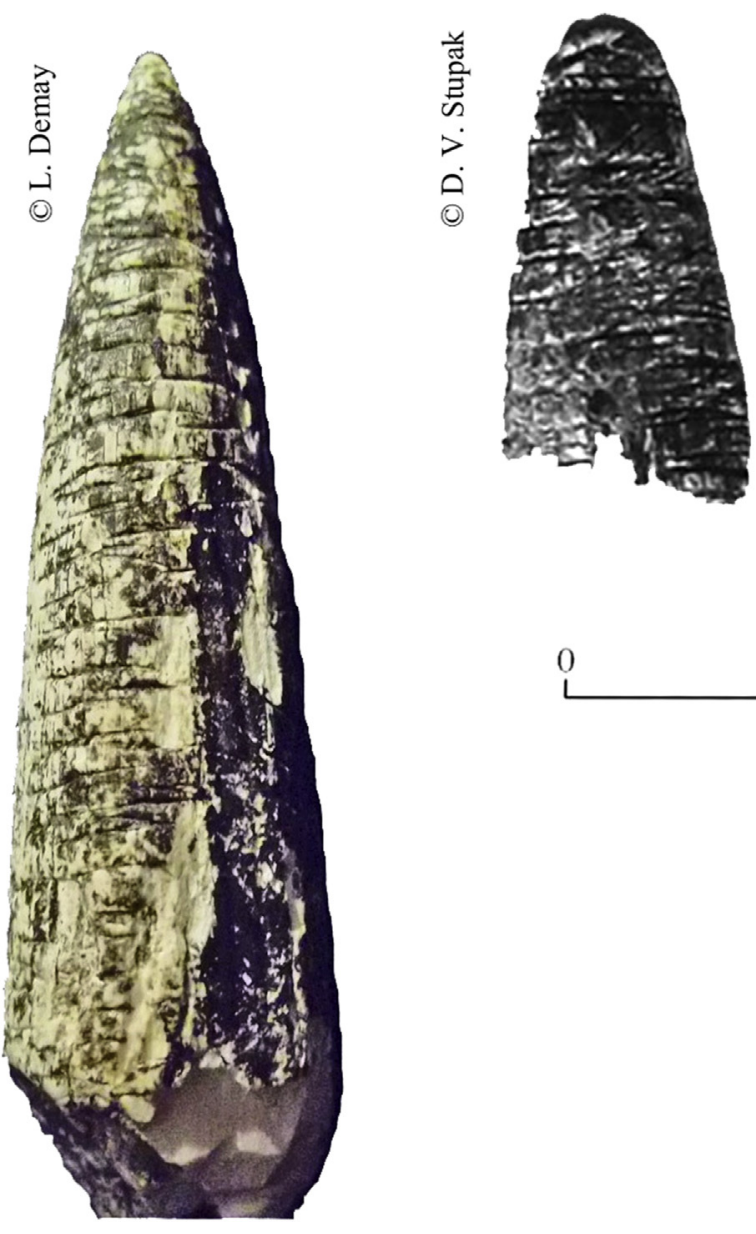

Fig. 16. Ivory points of Obollonia 2011-2013.

From the excavation of Obollonia - 2011-2013, fox is represented by 6 bone remains corresponding to at least 5 elements belong to at least one individual. Bones are represented by dental elements (a lower incisor, a lower canine and an upper canine), an ulna and a lumbar vertebra.

A brown bear (Ursus arctos) is represented by a proximal phalanx (Fig. 20).

In Pushkari 1 wolf is represented by 22 remains corresponding to at least 22 elements, mainly metapodials and phalanges. We have also a right mandible with three teeth $\left(\mathrm{P}_{3}, \mathrm{P}_{4}, \mathrm{M}_{1}\right)$, a left mandibula with a tooth $\left(\mathrm{M}_{2}\right)$, a lumbar vertebra, a humerus, an ulna and a radius belonging to at least one individual. In Pogon, a wolf is represented by an ulna.

In Pushkari 1, horse is represented by a single individual, according to the stages of eruption and tooth wear, is aged about 4-5 years. The reindeer is represented by a single individual. From a proximal end of humerus not totally epiphysed, this individual was less than 42 months old.

At Pogon, horse is represented by a fragment of mandibule, four ribs, a humerus, two femurs and at least two other indeterminate long bones A cervid is represented by a molar, an incisor, a rib, two femurs and at least two other indeterminate long bones, We do not know exactly the age of the Cervidae and the horse, but they are adults s.l.

In Pushkari 1 and Pogon, we have few remains of horse and reindeer. We do not know exactly the modalities of acquisition and exploitation of these animals. However, we identified cutmarks of butchering on a rib of reindeer (Fig. 21). Probably, these species have been hunted for food.

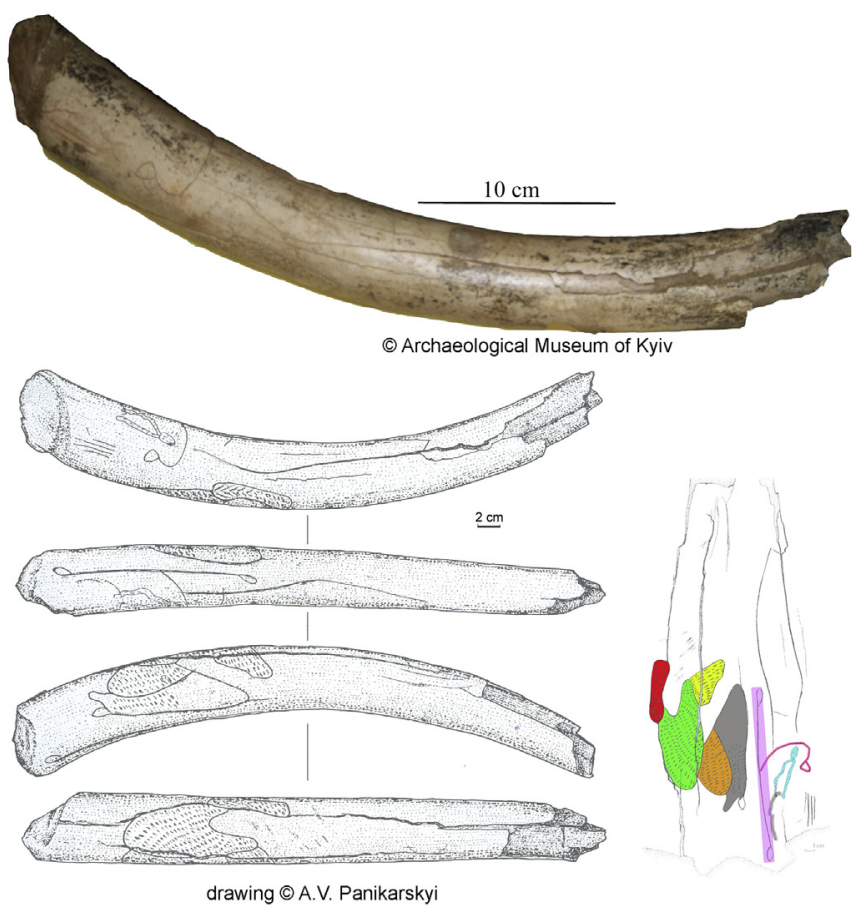

Fig. 17. Engraved tusk of Obollonia.

\subsubsection{Occupancy types and site functions}

In Pushkari 1-exc. VII, two fireplaces are present in the site. We excavated a small pit with bones of carnivores and another pit with bones of carnivores, in particular end limbs of fox, a rib of large mammal with cutmarks, burned bones, ashes and flakes. Maybe this one corresponds to a dumping zone. Vertebrae in connection could correspond to an area of butchering. Concerning the lithic study, tools were made and the site with local flint, in particular hunting artefacts (Fig. 22). Excavations and spatial distribution allowed us to define the site of Pushkari 1- exc. VII as a campsite with a spatial organization more developed than those known during this period, probably of recurrent short-termoccupations on

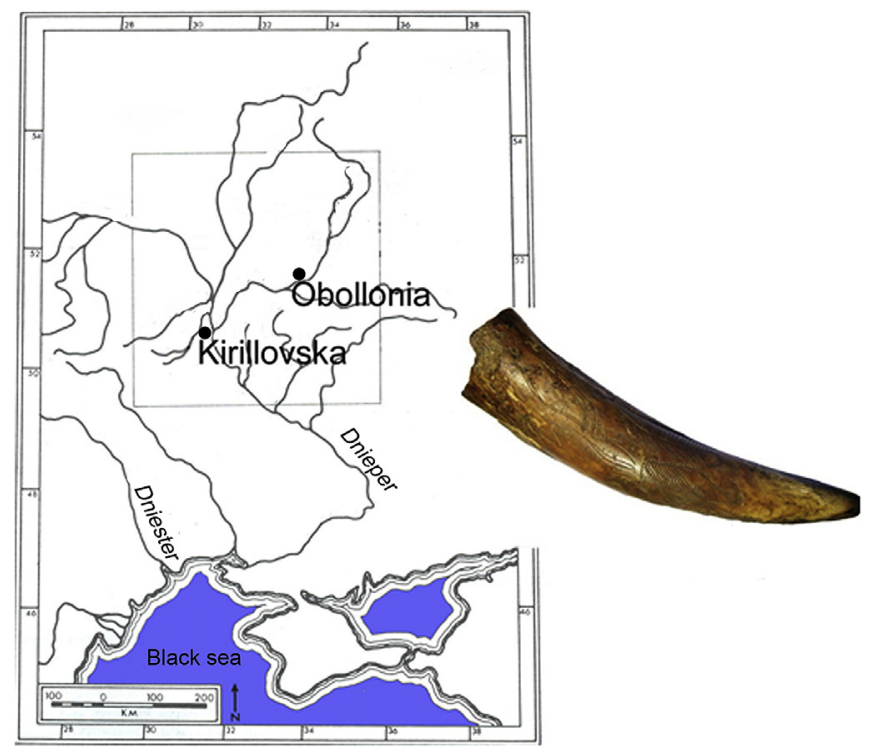

Fig. 18. Engraved tusk of Kirillovska (Khvoiko, 1913; 2008). 

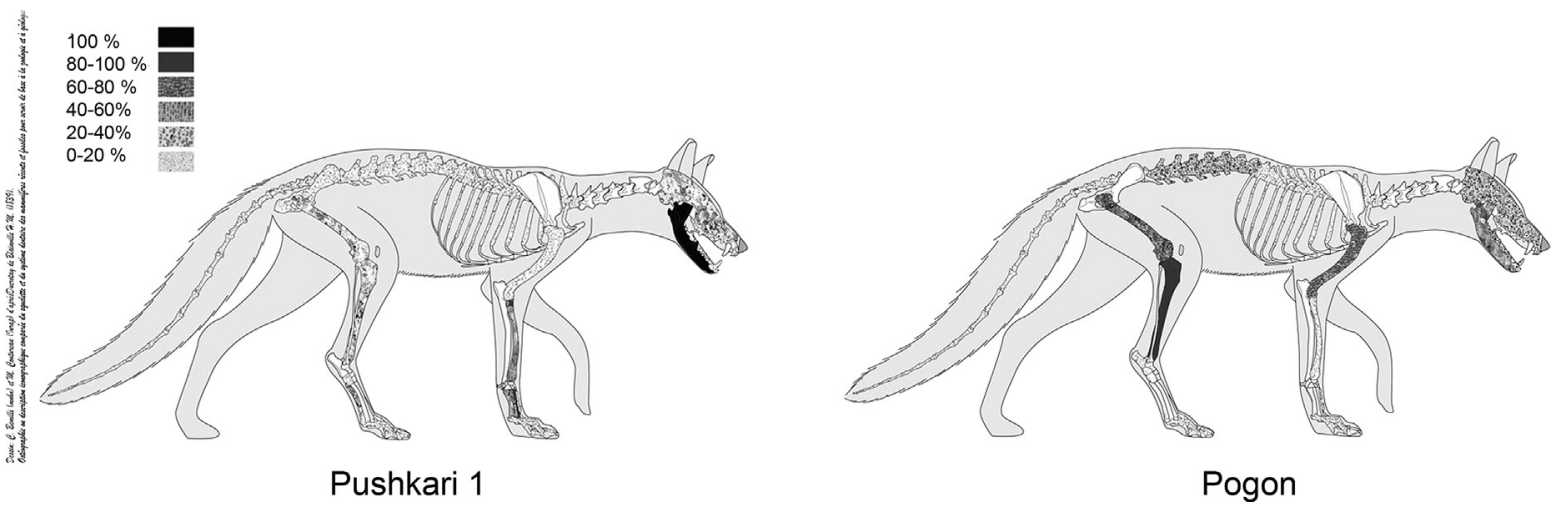

Fig. 19. Anatomical representation in percentage survivorship of Vulpinae of Pushkari 1 and Pogon.

different place on the promontory. It is quite similar to Kraków Spadzista, which is oriented on butchering activities (Wilczyński et al., 2012). We can propose that Pushkari 1 could be a mammoth kill and butchering site.

The promontory is characterized by a local flint of good quality which was used by human groups. So on the one hand the exploitation of flint is a main criterion. On the other hand, we argue that the recurrent presence of mammoth was an opportunity to hunt.

Despite the low quantity of faunal remains in Pogon we can venture a hypothesis about the faunal assemblage and human activities. Concerning mammoths, their role within the human strategies is quite difficult to determine. However, we know that their bones were used as combustibles and we can envisage that they were used as food. Human group(s) probably consumed Cervidae and horse. The presence of carnivores is indicated by their pelts. So human groups came in Pogon to establish temporary camps to get local flint to make tools relied to hunting and butchering showing a continuity of the activities on the promontory with Pushkari 1.

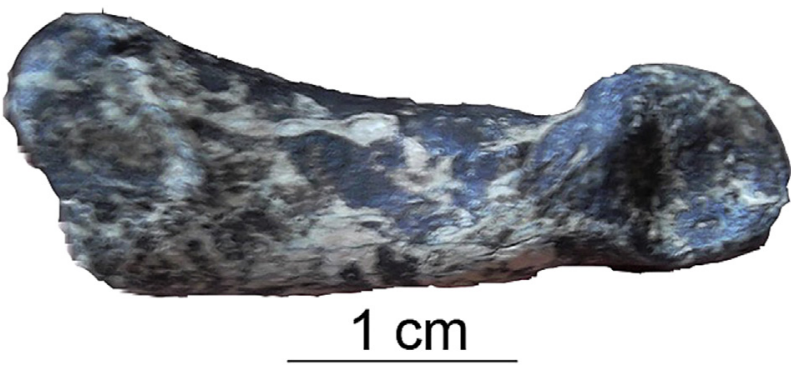

Fig. 20. Right proximal phalanx of Ursus arctos, in medial view, of Obollonia 2011, 2012, 2013 (ph. L. Demay).

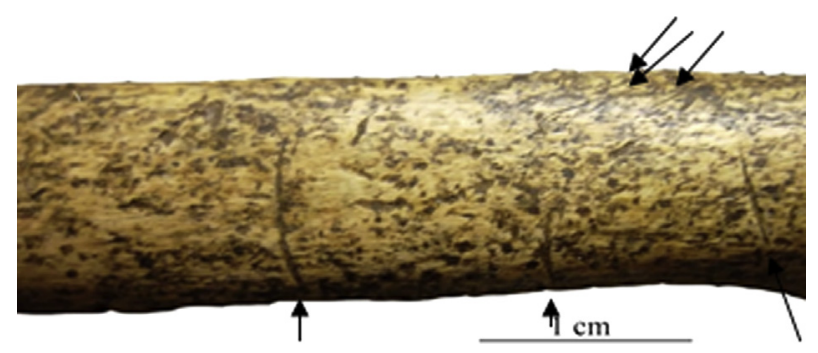

Fig. 21. Cutmarks on reindeer rib, Pushkari 1-exc. VII.
The site of Obollonia presents some burned bones, charcoals and ashes, but no fireplace was found. It is possible that this is in another place which was not excavated or that they were destroyed. Faunal remains were subjected to the alternation of the flooding and withdrawal of the Desna. From the zooarchaeological study, Obollonia was probably a temporary camp oriented on mammoth exploitation, for meat, marrow and to work ivory.

\subsubsection{Conclusions about the Desna valley sites}

In Pushkari 1, Pogon and Obollonia mammoth provided food and bones as combustibles, for storage, industry and art. So this animal influenced exploitation of the territory by human groups. The occupations were oriented on hunting and butchering activities mainly of mammoth. Other game was promptly exploited, such as horse and reindeer, and carnivores for fur. The occupations are temporary camp sites, repeatedly settled on different sectors on the promontory of Pushkari archaeological complex and in Obollonia, perhaps at the end of the winter/summer for these three sites. The establishments depended on game and the local flint. Pushkari 1 and Pogon show relatively developed organization of space, with areas of activities in Pushkari 1 and a likely light structure in Pogon. The exploitation of mammoth bones as building material is not as developed as anterior or posterior periods, but mammoth was always hunted. At Obollonia, the exploitation of ivory of mammoth as industry and artistic support was totally new in for this period in this area.

Moreover, the lithic industries of the three sites revealed specific facies. So in the same area during a relatively contemporaneous period we have different cultural facies oriented on mammoth.

\subsection{The Dniester valley}

Palaeolithic archaeological sites of the Western Ukraine are clustered along the Prut and Dniester Rivers. Different sites provided data enabling reconstruction of the paleoenvironment, chronology and cultures of human group during the Upper Paleolithic (notably Molodova V). The Gravettian sites of the Dniester valley, Molodova V, Korman IV, Babin I, Ciuntuleşti I (Noiret, 2009), have remains of mainly reindeer and horse, then mammoth and bison and wolf, fox, hare and few bones of red deer, megaceros, moose, rhinoceros, roe, and aurochs. The status of mammoth is difficult to understand; it is always represented, by few remains or many bones (Molodova V), but we cannot determine its consumption by human groups. During the Epigravettian occupations - Molodova V, Halich (Wojtal et al., 2001), Mejigirtzi (Koulakovska and Otte, 1998), Cosăuţi, Korman IV, Babin I, Climăuţi, Raşkov VII Voronovitsa I (Noiret, 2009)- hunting was 


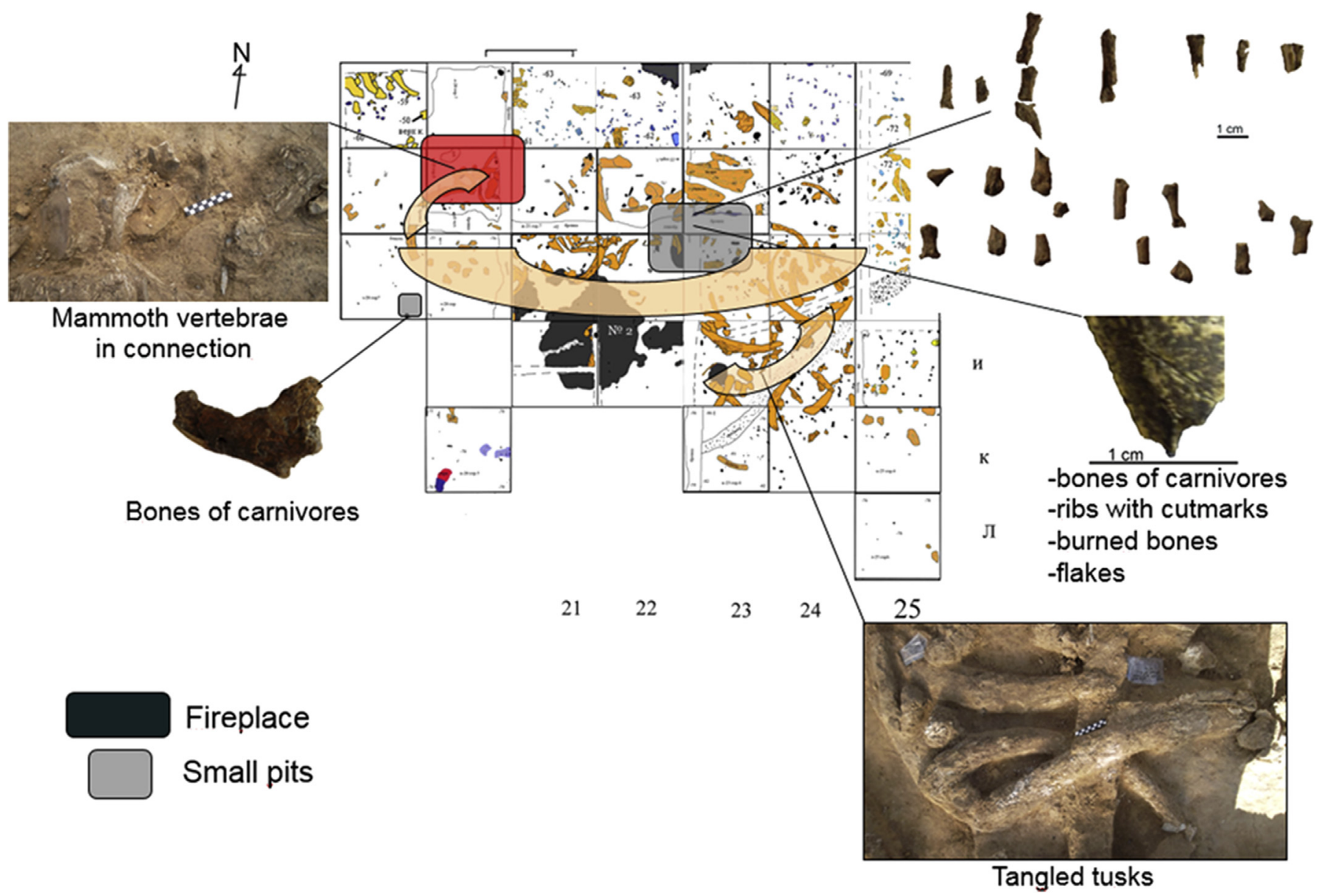

Fig. 22. Plan of excavation VII and spatial distribution, Pushkari 1 (Plan made by V.I. Belyaeva).

oriented on reindeer, then horse and bison, and the situation concerning mammoth is the same as during the Gravettian occupations. There are also remains of fox, hare and few remains of wolf, red deer, and moose.

During the first part of the Pleniglacial, between 23 000-20 $000 \mathrm{BP}$, palaeoclimatic variations took place. The intensification of cold and arid conditions is liable to force human groups to adapt to a changing environment. Little is known about this period, only a few assemblages in the Prut valley, Crasnaleuca-Stanişte and Ciuntu. Ongoing excavations continue to provide new data and Dorochivtsy III is the only pluristratified site of this period.

\subsubsection{Global quantification}

The zooarchaeological study of Dorochivtsy III was published (Demay et al., 2015, 2016). The faunal spectrum of Dorochivtsy III is relatively restricted. The tryptic reindeer-mammoth-horse is present in all the layers, often with fox. Proboscideans are well represented in terms of remains. Reindeer is predominant Lepus sp. is represented by two lower incisors in layer 6 (Table 6).

Table 6

Counting of the faunal remains of the main cultural layers of Dorochivtsy III.

\begin{tabular}{|c|c|c|c|c|c|c|c|c|c|c|c|c|}
\hline \multirow[t]{2}{*}{ Species } & \multicolumn{3}{|c|}{ Layer 3} & \multicolumn{3}{|c|}{ Layer 4} & \multicolumn{3}{|c|}{ Layer 5} & \multicolumn{3}{|c|}{ Layer 6} \\
\hline & NR & MNE & cMNI & NR & MNE & cMNI & NR & MNE & cMNI & NR & MNE & cMNI \\
\hline M. primigenius & 172 & 20 & 1 & 128 & 11 & 1 & 3 & 3 & 1 & 73 & 9 & 2 \\
\hline R. tarandus & 217 & 82 & 3 & 308 & 84 & 4 & 66 & 44 & 3 & 241 & 21 & 2 \\
\hline Equus sp. & 7 & 7 & 1 & 6 & 6 & 2 & 1 & 1 & 1 & 34 & 7 & 2 \\
\hline Vulpinae & 25 & 25 & 1 & 7 & 7 & 1 & & & & 4 & 4 & 1 \\
\hline Lepus sp. & & & & & & & & & & 2 & 2 & 1 \\
\hline Sub-total & 421 & 134 & 6 & 449 & 108 & 8 & 70 & 48 & 5 & 354 & 43 & 8 \\
\hline Large mammal & & & & 76 & 7 & & 11 & 2 & & & & \\
\hline Large/medium sized mammal & & & & & & & & & & 44 & 2 & \\
\hline Medium sized mammal & & & & 270 & 1 & & 22 & & & & & \\
\hline Small sized mammal & 3 & 3 & & & & & & & & 6 & 3 & \\
\hline Indeterminate & 241 & & & 228 & & & 1 & & & 713 & & \\
\hline Total & 662 & 134 & 6 & 1023 & 116 & 8 & 104 & 50 & 5 & 1118 & 48 & 8 \\
\hline
\end{tabular}




\subsubsection{Taphonomical processes}

Bones of layers 3, 4, 5 present well preserved surfaces whereas the surfaces of the bones of layer 6 are more damaged, due to the sandy deposit. Bones of mammoth and reindeer, in particular cranial, longs bones and ribs, are fragmented in particular, in layers 3, 4 and 6. This is quite typical of natural process of deterioration, excepted for long bones of reindeers relied with anthropogenic activities.

The four layers are characterised by few marks of weathering and run-off water but a high degree of oxidation on bones due to percolation of water. Bones of layer 5 are more affected by charriage-à-sec (Fig. 23).

Bones of layer 5 are more affected by root marks. Carnivores and rodents activities are sparsely represented (Fig. 23).

From these observations, we discern the bones of the layers were quickly buried. Absence of evidence of their potential activities suggests that carnivores were not responsible for the accumulation of bone material. The layers were well protected, but with some soil movements in particular in layer 6 . Regarding layer 5 , the bones were buried in the subsurface.

\subsubsection{Acquisition and treatment of fauna}

The reindeer of layers 3, 4, 5 and 6 of Dorochivtsy III are generally young individuals with some female and male adults. From the skeletal preservation in percentage survivorship, reindeers of layer 6 were butchered on the kill site and quarters of meat were brought to the camp, without pelvic bones. In layers 5-4-3, human groups took away from the camp only limbs and skulls with antlers (Fig. 24).

Layers 6-3 present impacts of fracturation, cutmarks for disarticulation and defleshing relied to skinning and butchering activities. Some long bones were used as combustibles. In layer 6, two awls were made from metapodials of reindeer (Fig. 25).

The site of Ciuntu, dated to $18510 \pm 200 \mathrm{BP}$ (OxA-4125), $21000 \pm 220 \mathrm{BP}$ (OxA-4426), $22100 \pm 220$ BP (OxA-4774), identified as Late Gravettian/Epigravettian, corresponds to several short-termed occupations oriented on hunting of reindeer and horses (David, 1980). This site furnished awls on metapodials of reindeer (Fig. 29).

Layer 5 presents non-shed antlers of young reindeer with cutmarks, slaughtered during the end of the winter season. Layer 4 presents two reindeer aged of at least two years. Births take place in June, so these individuals were slaughtered during the summer. Concerning the layer 3 , a juvenile reindeer is $5-8$ months old. From the birth season, this individual was slaughtered between November and February. Another reindeer with non-shed antler is around two years old. The reindeers of layer 3 were slaughtered during the winter season (Fig. 26). There were different seasons of occupations in summer and in winter.

The mammoths of Dorochivtsy III are young individuals in all the layers. There are represented by cranial, long and flat bones. Bones were used as combustibles. In layer 6 , we studied 156 burned bone remains, 148 in layer 4 and 148 in layer 3. The majority of these remains belong to ribs and long bones of mammoth.

In layer 6 , we found three ivory points (b,c,d), two of them presenting grooves (c, d). In layer 3 a fragment of ivory of mammoth presents a smooth and corrugated surface which could result from an anthropogenic impact (a) (Fig. 27)

Layer 6 presents an engraved tusk belonging to a young adult. The engravings were processed with thin carving to elaborate meanders and a figure (Rydush, 2008; Koulakovska et al., 2012) (Fig. 28). The site of Climăuţsi II, upper layer, dated around $20350 \pm 230 \mathrm{BP}$, furnished some pieces on ivory, as bracelets, pierced staff and points Borziac (Fig. 29).

Horses are represented by some elements, mainly long bones belonging to juvenile, young individual, and mature adult. Layers 63 present impacts of fracture, cutmarks for disarticulation and defleshing relied to butchering activities for reindeer and horse.

Fox is represented by few bones of all anatomical parts, so they were probably kept complete on the site. In layer 4 , a metapodial of fox has clear marks of skinning. Probably, some foxes were hunted for their pelts.

\subsubsection{Occupancy types and site functions}

In all the layers, the small number of animals involves short human occupations.

Layer 6 is characterized by varied activities: lithic industry, butchering, bone industry and aestheticism. This layer is characterised by short-termed occupation(s), longer than in other layers. Concerning the spatial distribution, layer 6 hats charcoals, but was disturbed by phenomena of erosion, cryoturbation and soil movements, and the remains are divided.
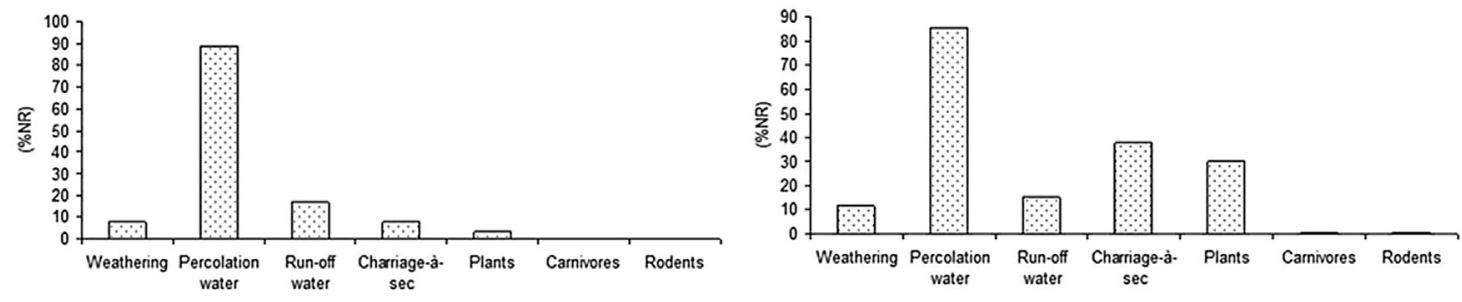

Layer 6

Layer 5
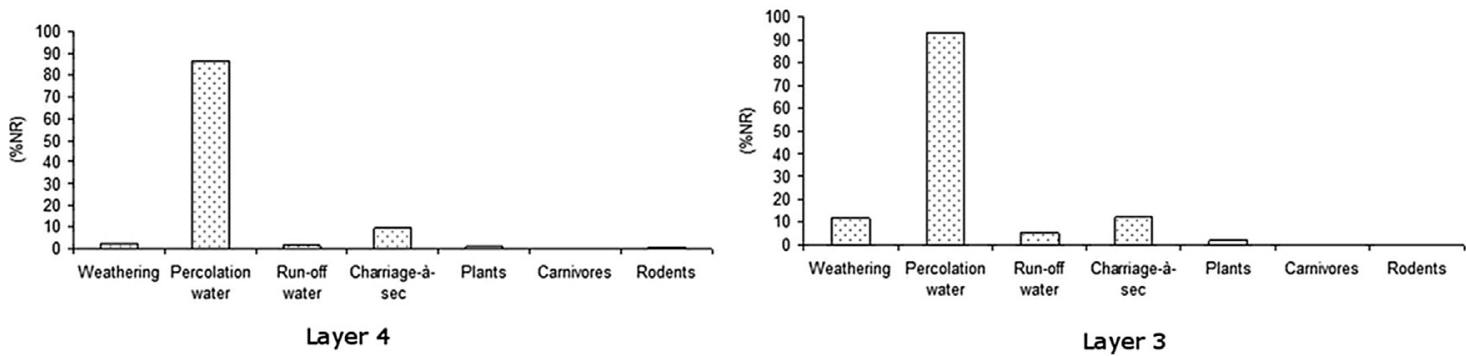

Fig. 23. Alterations due to climato edaphic and non-anthropogenic biological agents of Dorochivtsy III- 1.6-3. 
NR: 241 ; MNE: 21 ; cMNI: 2

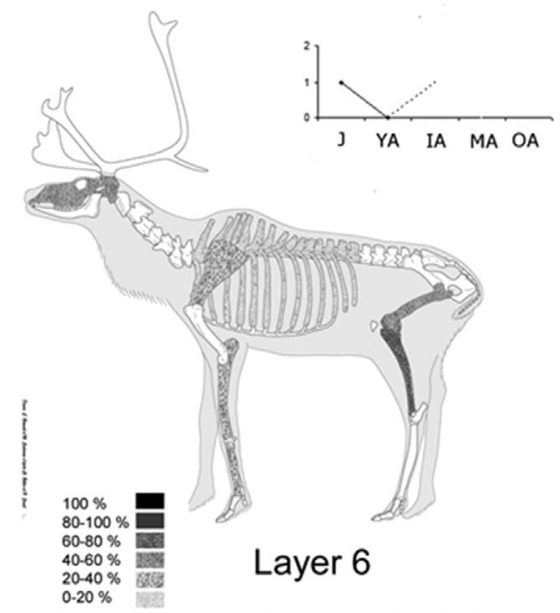

NR: 308; MNE: 84 ; cMNI: 4

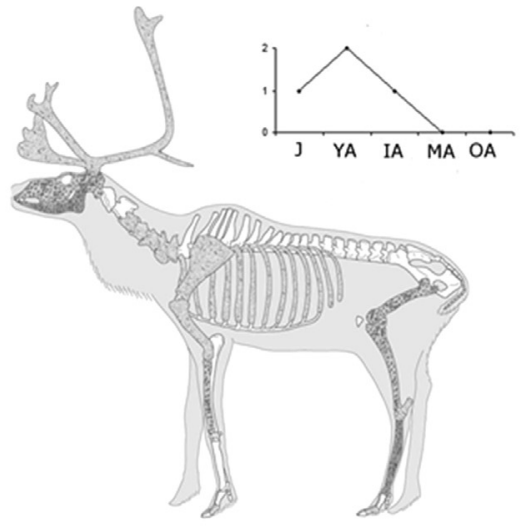

Layer 4
NR: 66; MNE: 44; cMNI: 3

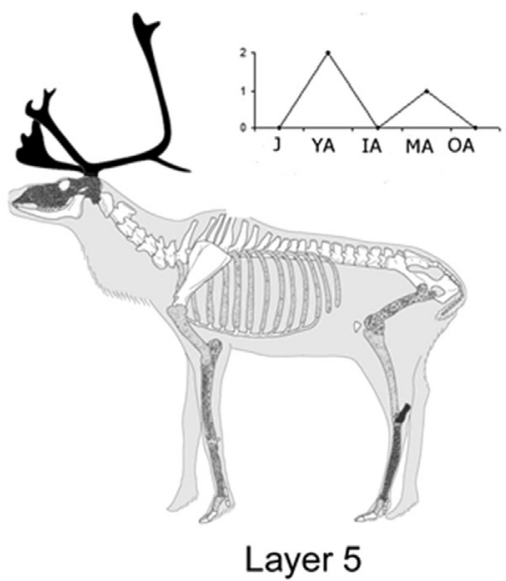

NR: 217 ; MNE: 82 ; cMNI: 3

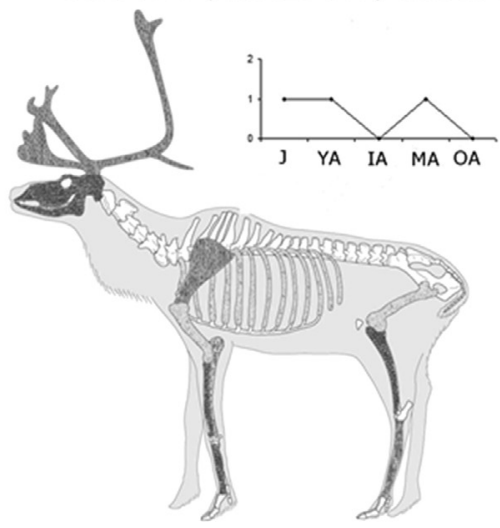

Layer 3

Fig. 24. Skeletal preservation in \%survivorship of reindeers of the layers 6-3 of Dorochivtsy III.

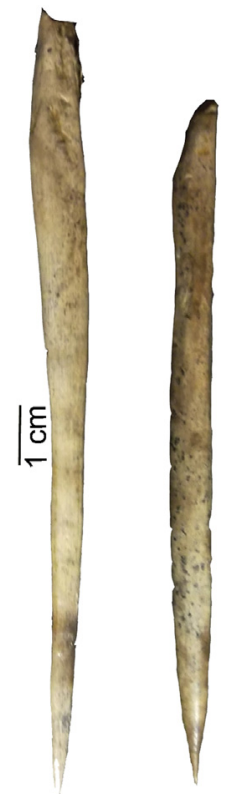

Fig. 25. Awls made on metapodials of reindeer, layer 6, Dorochivtsy III. (Photo: L. Demay).
Layer 5 is based on exploitation of flint and mainly on hunting of reindeer. It is a very short term occupation of a small human group. The site does not present any area of activities or any charcoals.

Layer 4 is based on exploitation of flint and on hunting and butchering of reindeer and probably horses, together with exploitation of fur of fox. It is a short-term occupation. The layer has charcoals but does not present obvious areas of activities.

Layer 3 is based on exploitation of flint and hunting and butchering of reindeer. Some fragments of antler and a fragment of ivory bear anthropogenic impact also. This layer shows a hearth with a concentration of lithic artefacts and bones.

Concerning the culture of the Moldavia area, during the Gravettian and the Epigravettian, called Molodovian, the main features are the acquisition of local flint, with few settled camp sites, bounded with reindeer hunting, and there are few artifacts reflecting bone industry or artistic pieces (Noiret, 2009). The site of Crasnaleuca-Staniște, layer VII, dated to $21700 \pm 800 \mathrm{BP}(\mathrm{GrN}-$ 12671), represents a flint workshop. Bone remains are altered, with some bones of bovid (Paŭnescu, 1999) (Fig. 29). The layers of Dorochivtsy III are quite correlated to the Molodovian features. However, layer 6 is more different than what we know before, presenting activities more varied than expected.

\subsubsection{Conclusions about the Dniester valley site}

Among the seven Upper Palaeolithic layers, 6, 5, 4 and 3 of Dorochivtsy III testify to the activities of human group during the 


\begin{tabular}{|c|c|c|c|c|c|c|c|c|c|c|c|}
\hline January & February & March & April & May & June & July & August & September & October & November & December \\
\hline \multicolumn{12}{|c|}{ Layer 5} \\
\hline & & & & & & & & & & & \\
\hline \multicolumn{12}{|c|}{ Layer 4} \\
\hline & & & & & & & & & & & \\
\hline \multicolumn{12}{|c|}{ Layer 3} \\
\hline
\end{tabular}

Fig. 26. Seasonal slaughter of the reindeers, Dorochivtsy III.

little known Upper Pleniglacial period. The zooarchaeological study allowed us to recognize reindeer, horse, mammoth and fox. Within layers 5, 4 and 3, the human activities are in connection with use of the local flint and hunting of great mammals, in particular reindeer, then horses. Concerning mammoths, we do not know what the modalities of acquisition and exploitation are. Fox was exploited for fur. The sites suggest recurrent short-termed occupations during different seasons. Layer 5 corresponds more to a hunting stopping place. These behavioural activities are quite typical of the Molodovian complex.

Layer 6 is remarkable because of previously unseen practises. The lithic assemblage combines with bone industry and engraved tusk is a new kind of cultural elements in this area. This profile corresponds to an ancient Epigravettian. This layer shows the diversity of human activities during the Upper Pleniglacial and to the particular status of mammoth ivory as artistic medium. So it is possible that we have a continuity of occupations and cultural features through the time, but probably problems of preservation of the archaeological occupations in the Dniester valley.

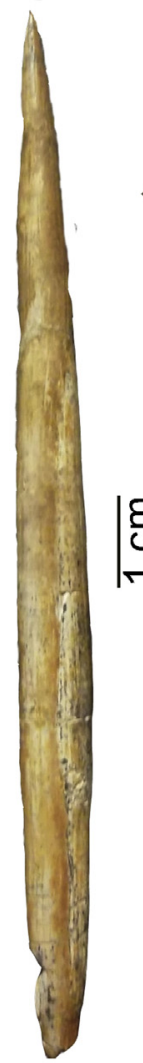

(b)

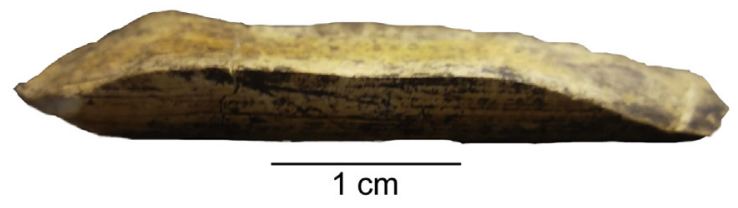

(a)

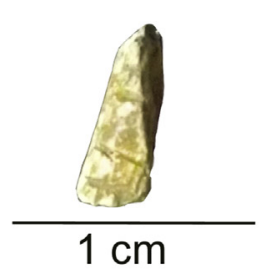

(c)

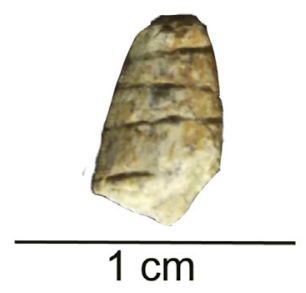

(d)
Fig. 27. Industry on mammoth ivory of Dorochivtsy III. a) flake, 1.3; b-c-d) points, 1.6. (Ph: L. Demay).

\section{Discussion}

These sites permit understanding the strategies of game exploitation during the first part of the Upper Pleniglacial. Comparing them, we can better understand the situation in the East European plain.

\subsection{Context in both valleys}

During this period between the Desna and Dniester valleys, the climate is similar with an average of $0-6{ }^{\circ} \mathrm{C}$ to the year, and around $-13{ }^{\circ} \mathrm{C},-6^{\circ}$ in the coldest periods (Banks et al., 2008). The

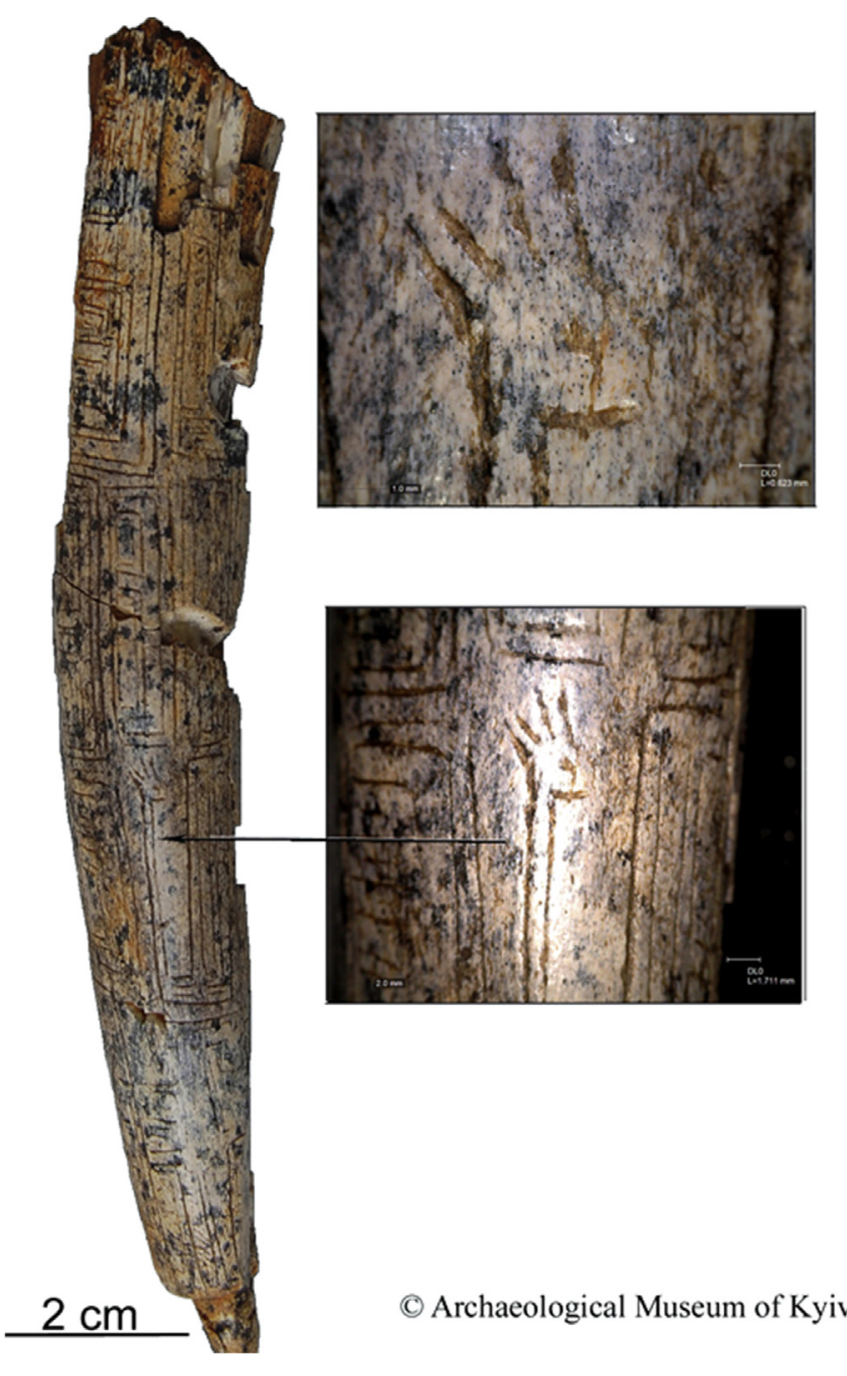

Fig. 28. Mammoth tusk with engravings, layer 6, Dorochivtsy III. 


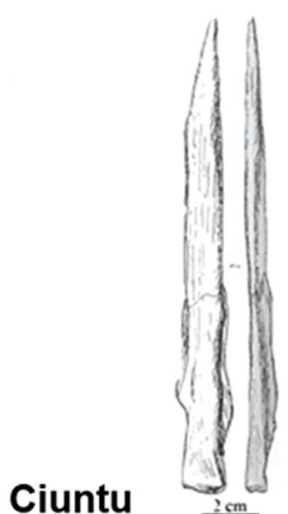

Awl on metapodial of reindeer (C) P. Noiret, from borziac)
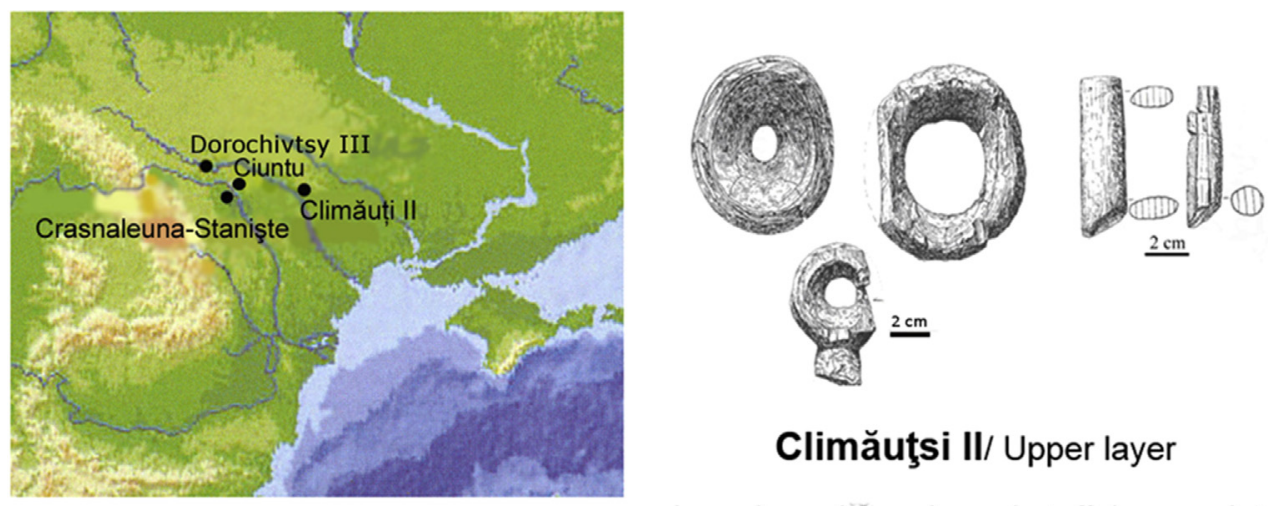

$\underline{2 \mathrm{~cm}}$

\section{Climăuţsi II/ Upper layer}

Ivory bracelets, pierced staff, ivory points

(৫) P. Noiret, from Borziac, David, Obadă)

Fig. 29. Archaeological sites of the Dniester valley with bones and ivory artefacts.

vegetation is typical of periglacial steppe with halophyte plants and thinning forest in river valleys (Grichuk, 1982). We have a context relatively similar than the localization of the occupations in valleys. They permit human groups to be protected, to have access to water and are strategic places to watch the displacements of animals. However the topography is different between both regions. The Desna valley includes indented ravines forming narrow valleys whereas the Dniester is composed of meanders with lateral valleys. In both valleys human occupations are localized on plateau or terrace in Pushkari 1, Pogon and Dorochivtsy III. This type of topography is exploited in the Dniester valley to hunt reindeer and horse and in the Desna valley to hunt mammoth. In Obollonia they choose a floodplain to exploit mammoth. All these sites are characterized by a dry and cold climate, however the presence of riparian trees permits the development of vegetation forming corridors which permits the circulation of fauna and human groups. The presence of flint of good quality is a main criterion for settlements. For all these sites, a local flint was exploited directly on the sites for Pushkari 1, Pogon and Dorochivtsy III and a little bit more far from Obollonia.

\subsection{Behavioral activities and functions of the sites}

All these sites are characterized by recurrent occupations with relatively few developed settlement structures, excepted in Pushkari 1 . We have a common exploitation of the tryptic reindeermammoth-horse and some carnivores. Bones were systematically used as combustibles, in particular bones of mammoth. In the Desna valley, in Pushkari 1, Pogon and Obollonia the subsistence strategies are mainly oriented on mammoth. In the Dniester valley, in layers 3-4-5 of Dorochivtsy III, the subsistence strategies are mainly oriented on reindeer. Concerning layer 6 of Dorochivtsy III, food activities are oriented on reindeer, and mammoth was exploited in terms of use of ivory. In Obollonia, a unique kind of exploitation of ivory during this period made points with grooves and engraved tusks.

Finally, all these sites are temporary camps oriented on hunting and butchering activities in strong bounds with the local flint. These sites are specialized about hunting. They also show the participation of knowledge concerning work of ivory. The presence of such artistic pieces as engraved tusks in short-termed occupations is questionable.

\subsection{Cultural particularities}

The sites of Pushkari 1-Pogon, Obollonia and the layer 6 of Dorochivtsy III present atypical facies linked to lithic industry and bone artefacts: the Pushkarian, an Epiaurignacian and an ancient Epigravettian. In the Desna valley at the same area during a relatively contemporaneous period, we have different cultural facies and it is the same for Dorochivtsy III/1.6 in the Dniester valley. Obolonia is the first manifestation of Epiaurignacian industry in the Middle Desna region and together with sites of Pushkari group is the one of the oldest settlement in this territory. Dorochivtsy III/1.6 also has an ancient date of Epigravettian features in the Dniester valley. These occupations could be human groups coming regularly from the south of the East European plain to the north. However, the features are specific to the sites. We could also propose that it may be ethnic groups which are staying in the area during this period. These ethnical groups could come from anterior movements of Gravettian peoples from Central Europe or/and from the southern regions of the East European plain. The period of the Last Glacial Maximum could have generated some interlocks causing new behaviors visible in the manufacture (lithic tools, bone modification, art), but human groups continued their traditional exploitation of area orienting their activities more on hunting than lithic acquisition, always on reindeer in the Dniester valley and on mammoth in the Desna valley.

These sites are really important for the understanding of cultural processes in the Eastern European Upper Palaeolithic, and particularly for the understanding of Epigravettian origin.

\section{Acknowledgments}

The zooarchaeological research was conducted in the frame of French Minister of Foreign Affairs PHC Program: Animal resources and subsistence of Palaeolithic hunter-gatherers in Ukraine, coordinated by S. Péan, P. Shydlovskiy. This study was funded by cooperation project CNRS-NASU (EDC25214) (Centre National de la recherche scientifique/National Academy of Sciences of Ukraine) "Les chasseurs paléolithiques de la vallée du Dniestr", 2012-2013, directed by L. Koulakovska and M. Patou-Mathis.

We thank the organizers of the XVII World UISPP Congress (Burgos, 2014) and the organizers of the session A9b The Study of the Environment and the Landscape in the Reconstruction of the Economic and Social Activities during the Upper Paleolithic. 
Methodological Approaches and Case of study, C. Cacho, P. Ortega, L. Iakovleva. We thank D. Yu. Nuznyi, M. V. Sablin, G.I. Klopatchev, P. Wojtal, J. Wilczyński, G. Haynes, L. Crépin, F. Djindjian, and for their advices. We thank the teams of the different sites and the team of the Museum of Archaeology of Kiev. We thank F. Lanoë and the reviewers.

The participation to the congress was funded by: Histoire Naturelle de l'Homme Préhistorique (UMR 7194); Équipe II Comportements des Néandertaliens et des Hommes anatomiquement modernes replacés dans leur contexte paléoécologique.

\section{References}

Agenbroad, L.D., 1994. Taxonomy of North American Mammuthus and biometrics of the Hot Springs mammoths. In: Agenbroad, L.D., Mead, J.I. (Eds.), The Hot Springs Mammoth Site. Fenske Printing, Rapid City, SD, pp. 158-207.

Altuna, J., 2004. Biometrical study of Vulpes vulpes L and Alopex lagopus L. A contribution to their differentiation in the Cantabrian Paleolithic sites. MUNIBE (Antropologia-Arkeologia) 56, 45-59.

Amirkhanov, H.A., 1998. Vostocnyj gravett ili gravettoidnye industrii Central'noj: Vostocnoj Evropy? In: Amirkhanov, H.A. (Ed.), Vostocnyj gravett. Izdanie finansirovano rossijskim gumanitarnym naucnym fondom pri uchastii instituta "Otkrytoe Obschestvo". Scientific World, Moskow, pp. 15-34 (in Russian).

Averianov, A., 1996. Sexual Dimorphism in the Mammoth Skull, Teeth, and Long Bones. In: Shoshani, J., Tassy, P. (Eds.), The Proboscidea. Oxford University Press, Oxford, pp. 280-288.

Banks, W.E., d'Errico, F., Peterson, A.T., Vanhaeren, M., Kageyama, M., Sepulchre, P., Ramstein, G., Jost, A., Lunt, D., 2008. Human ecological niches and ranges during the LGM in Europe derived from an application of eco-cultural niche modeling. Journal of Archaeological Science 35 (2), 481-491.

Barone, R., 1986. Anatomie comparée des mammifères domestiques: Ostéologie. Vigot Frères, Paris.

Beauval, C., Michel, P., Tastet, J.-P., 1998. L'éléphant antique de Soulac (Gironde, France). Quaternaire 9 (2), 91-100.

Belyaeva, V.I., 1997. Pushkari I Excavations. The Collection of Pushkari, I. Russian Academy of Sciences, St.-Petersburg, pp. 5-18 (in Russian).

Belyaeva, V.I., 2000. Pushkari I characteristics. L'Almanach archéologique 9, 45-152 (in Russian).

Belyaeva, V.I., 2002. Pushkari I lithic industry. In: Praslov, N.D. (Ed.), Uppe Paleolithic-Upper Pleistocene: Dynamics of Natural Events and Archaeological Cultures/International Congress, in Honour to Rogatchev A.N.. St.-Petersburg, pp. 133-137 (in Russian).

Belyaeva, V.I., 2004. Orudnie I morfologi'eskie formu kremnevogo inventarie Pushkarevskich stojenok. Archeologicheskii almanac 16, 251-262 (in Russian).

Belyaeva, V.I., 2009. Nekotorue Obobchenie polevuch issledovanii v Pushkari 1. S.N.Bibikov and prehistoric archeology. Nauka, Saint Petersburg, pp. 181-187 (in Russian).

Binford, L.R., 1979. Organization and formation processes: looking at curated technologies. Journal of Anthropological Research 35, 255-273.

Boriskovski, R.I., 1949. Paleolit I Neolit ukraini. In: Matériaux et recherches sur l'archéologie d'URSS, XL, pp. 155-183 (in Russian).

Boriskovski, P.I., 1953. Paleolithic in Ukraine: Materials and Researches about Archaeology of USSR. Academy of Sciences of USSR, Moscow-Leningrad.

Borziac, I.A., Kulakovska, L.V., 1998. Gravet podnistrovie. Zagalnij ogljad. Arkeologie 5, 55-64 (in Ukrainian).

Borziac, I., Chirica, V., 1999. Considerations concernant le Gravettien de l'espace compris entre le Dniestr et les Carpates. Préhistoire Européenne 14,67-78.

Borziac, I., Haesaerts, P., Chirica, V., 2005. Cadrul cronostratigrafical Paleoliticului superior cuprins între Carpaţii Orientali și Nistru. Revista Arheologică. S.N., 1, nr. 2, pp. 168-201.

Bouchud, J., 1953. Signification climatologique des faunes paléolithiques. Bulletin de la Société Préhistorique Française 50, 431-435.

Bouchud, J., 1954. Dents de Rennes, bois de Rennes et migrations. Bulletin de la Société Préhistorique Française LI, 340-345.

Chernysh, A.P., 1954. Karta paleolitu USSR. Mamerialu i boslibjehhja po arkeolosi. In: Naukauvi zalusku filialu AN USSR II. Nauka, Kiev (in Russian).

Chernysh, A.P., 1973. Paleolit i Mesolit of the Dnestr Area (kartie i katalogi). Nauka, Moscow (in Russian).

Chernysh, A.P., 1985. Verchnij paleolit. In: akeologii ukraini. I. Naukova Dumka, Kiev, pp. 43-63 (in Russian).

Chirica, V., Văleanu, M.-C., 2007. Établissements et habitations préhistoriques : structure, organisation, symbole. In: Actes du colloque de Iaşi, 10-12 Décembre 2007. Académie roumaine, Filiale de Iaşi, Institut d'archéologie Iaşi.

Clark, P.U., Marshall, S.J., Clarke, G.K.C., Hostetler, S.W., Licciardi, J.M., Teller, J.T. 2001. Freshwater forcing of abrupt climate change during the last glaciation. Science 293, 283-287.

Coppens, Y., 1965. Les élephants du Quaternaire français: dentition, systématique, signification et préhistoire. In: Actes du XVIe Congrès Préhistorique de France, Monaco, 1959. Société Préhistorique Française, pp. 403-431.

Covalenco, S.I., 1995. The chronological division of the Late Palaeolithic sites from Moldavian Dniestr area. Préhistoire européenne 7, 153-167.
Covalenco, S.I., 2003-2004. A contribution to the problem of the Dniester EpiAurignacien. Stratum Plus 1, 301-306.

David, A.I., 1980. Teriofauna pleistocena Moldavii. Chișinau (in Russian).

Demay, L., Patou-Mathis, M., Koulakovska, L., 2015. Zooarchaeology of the layers from Dorochivtsy III. Quaternary International 359-360, 384-405.

Demay, L., Péan, S., Belyaeva, V.I., Vasil'ev, P.M., Patou-Mathis, M., 2016. Zooarchaeological study of an Upper Palaeolithic site with mammoth remains, Pushkari I-excavation VII (Chernigov oblast, Ukraine). Quaternary International 406 (Part B), 183-201.

Djindjian, F., Kozlowski, J.K., Otte, M., 1999. Le Paléolithique supérieur en Europe. Armand Colin, Paris.

Djindjian, F., 2002. Ruptures et continuités dans les industries du maximum glaciaire en Europe centrale et orientale: la question de l'Epigravettien. In: Sinitsyn, A., Sergin, V., Hoffecker, J. (Eds.), Trends in the Evolution of the East European Palaeolithic. Kostienki in the Context of the Palaeolithic of Eurasia. Series Research I. Institute of the History of Material Culture, Saint-Pétersbourg, pp. 53-62.

Driesch, A. von den, 1976. A Guide to the Measurement of Animal Bones from Archaeological Sites. Harvard University (Peabody Museum of Archaeology and Ethnology, Cambridge (Mass.).

Eisenmann, V., 1991. Les chevaux quaternaires européens (Mammalia, Perissodactyla); Taille, typologie, biostratigraphie et taxonomie. Geobios 24 (6), 747-759.

Enloe, J.G., 1997. Seasonality and age structure in remains of Rangifer tarandus: Magdalenian hunting strategy at Verberie. Anthropozoologica, 25-26, 95-102.

Fisher, D.C., Tikhonov, A.N., Kosintsev, P.A., Rountrey, A.N., Buigues, B., van der Plicht, J., 2012. Anatomy, death, and preservation of a woolly mammoth (Mammuthus primigenius) calf, Yamal Peninsula, northwest Siberia. Quaternary International 255, 94-105.

Fladerer, F.A., Salcher-Jedrasiak, T.A., Händel, M., 2015. The fat of the land: tales from a Gravettian hearth (27,000 years BP) at Krems-Wachtberg (Lower Austria). In: $\mathrm{VI}^{\text {th }}$ International Conference on Mammoths and Their Relatives, 05-12 Mai 2014. Grevena \& Siatista, Griechenland.

Gribchenko, Yu. N., 2006. Lithology and stratigraphy of loess-soil series and cultural layers of Late Palaeolithic campsites in Eastern Europe. Quaternary International 152-153, 153-163.

Gribchenko, Yu. N., Belyaeva, V.I., Kurenkova, E.I., 2011. Archeologie i paleogeografie Pushkarevskich stoienok bassejna Desnu. Vestnik antropologii 15.

Grichuk, V.P., 1982. Vegetation of Europe during Late Pleistocene. In: Gerasimov, I.P., Velichko, A.A. (Eds.), Paleogeography of Europe during the Last One Hundred Thousand Years. Nauka, Moscow, pp. 79-85.

Grigor'ev, G.P., 1970. Verchnij paleolit. In: Kamennyi vek na territorii SSSR. Nauka, Moscou, pp. 43-63 (in Russian).

Haesaerts, P., Borziac, I., Van der Plicht, J., Damblon, F., 1998. Climatic events and Upper Palaeolithic chronology in the Dniestr Basin: new radiocarbon results from Cosautsi. In: Mook, W., Van der Plicht, J. (Eds.), Proceedings of the 16th International 14C Conference, Tucson, pp. 649-657. Radiocarbon, 20(2).

Haesaerts, P., Borziak, I., Chirica, V., Damblon, F., Koulakovska, L., Van der Plicht, J., 2003. The east Carpathian loess record: a reference for Middle and Late Pleniglacial stratigraphy in Central Europe. Quaternaire 14 (3), 163-188.

Haynes, G., 1987. Proboscidean die-offs and die-outs: age profiles in fossil collections. Journal of Archaeological Science 14 (6), 659-668.

Haynes, G., 1991. Mammoths, Mastodonts and Elephants, Biology, Behavior and the Fossil Record. Cambridge Press, Cambridge.

Hillson, S., 1986. Teeth. Cambridge University Press, Cambridge.

Hufthammer, A.K., 1995. Age determination of Reindeer (Rangifer tarandus L.), Archaeozoologia 7 (2), 33-42.

Koulakovska, L.V., Otte, M., 1998. Mejigirzi. Préhistoire Européenne 13,149-166.

Koulakovska, L.V., Usik, V.I., Haesaerts, P., Ridush, B., Gerasimenko, N., Proskurniak, Y., 2011. Investigations of the Dorochivzi III Upper Paleolithic site. Kamiana doba ukraini 14, 74-87.

Koulakovska, L.V., Usik, V.I., Haesaerts, P., 2012. Dorochivtsy III- Gravettian site in the Dniester valley (Ukraine). Stratum Plus 1, 131-150.

Koulakovska, L.V., Usik, V.I., Haesaerts, P., Ridush, B., Uthmeier, T., Hauck, T.C., 2015. Upper Paleolithic of Middle Dniester: Doroshivtsi III site. Quaternary International 359-360, 347-361.

Koulakovska, L., Usik, V., Rydush, B., Péan, S., 2008. Paleolitina stojanka Dorochivtsy III v Cerednoumu Podnistrov'i (Pooeredne novidomlennja). In: Materiali mijnarodnoi naukovoi konferenchii Padomisle ta jogo istorija 3-4, jovtnja 2006, pp. $51-52$.

Kozlowski, J.K., 1986. The Gravettian in Central and Eastern Europe. In: Wendorf, F., Close, A. (Eds.), Advances in World Archaeology, vol. 5. Academic Press, Orlando, pp. $131-200$.

Khvoika, V.V., 2008. Drevnie obitateli Srednego Pridneprovie i ich kultura v postorieskie vremena (s kommentariemi i illustraciemi). Na NANU (re-edited from 1913), 160 p. (in Russian).

Kuntz, D., 2011. Ostéométrie et migration(s) du renne (Rangifer tarandus) dans le sud-ouest de la France au cours du dernier Pléniglaciaire et du Tardiglaciaire (21 500-13 000 cal. BP). Thèse de Doctorat. Université de Toulouse II, France.

Lavocat, R., 1966. Atlas de Préhistoire. Tome III. Faunes et Flores préhistoriques de l'Europe Occidentale. Éditions N. Boubée et Cie, Paris.

Laws, R.M., 1966. Age criteria for the African elephant Loxodonta a. Africana. East African Wildlife Journal 4, 1-37. 
Lessertisseur, J., Saban, R., 1967a. Squelette appendiculaire. In: Grassé, P.P. (Ed.), Traité de zoologie, anatomie, systématique, biologie, XVI, Mammifères, Masson, Paris, pp. 709-1078.

Lessertisseur, J., Saban, R., 1967b. Squelette axial. In: Grassé, P.P. (Ed.), Traité de zoologie, anatomie, systématique, biologie Mammifères, Tégument et squelette, XVI, Fascicule I. Masson, Paris, pp. 585-708.

Lincoln, G.A., Tyler, N.J.C., 1994. Role of gonadal hormones in the regulation of the seasonal antler cycle in female reindeer, Rangifer tarandus. Journal of Reproduction and Fertility 101, 129-138.

Lister, A.M., 1996. Sexual dimorphism in the mammoth pelvis: an aid to gender determination. In: Shoshani, J., Tassy, P. (Eds.), The Proboscidea. Oxford University Press, Oxford, pp. 254-259.

Lister, A.M., 1999. Epiphyseal fusion and postcranial age determination in the woolly mammoth, Mammuthus primigenius (Blum.). Deinsea 6, 79-88.

Lyman, R.L., 1994. Vertebrate Taphonomy. Cambridge University Press, Cambridge.

Lyman, R.L., 2008. Quantitative Paleozoology. Cambridge University Press, Cambridge.

Miller, F.L., 1972. Eruption and attrition of mandibular teeth in barren-ground caribou. Journal of Wildlife Management 36, 606-612.

Miller, F.L., 1974. Biology of the Kaminuriak Population of Barren Ground Caribou. Part 3: Taiga Winter Range Relationships and Diet. Canadian Wildlife Service Reports, Ottawa.

Murray, N.A., 1993. The Behavioural Ecology of Reindeer (Rangifer tarandus) during the Last Glaciation in Britain and its Implications for Human Settelment, Subsistence and Mobility. UnpublishEd. Ph. D. thesis. University of Edinburgh, Scotland.

Noiret, P., 2004. Le Paléolithique supérieur de la Moldavie. L'Anthropologie 108 (3-4), 425-470.

Noiret, P., 2007. Les industries aurignaciennes et « aurignacoïdes » en Moldavie après 30.000 BP. Annales d'Université « Valahia » Târgoviște, Section d'Archéologie et d'Histoire VIII-IX, 91-105.

Noiret, P., 2009. Le Paléolithique supérieur de la Moldavie. In: Essai de synthèse d'une évolution multi-culturelle. Université de Liège, Liège.

Nuzhnyi, D. Yu., 1992. Rozvitok mikrolitichnoi texniki v kam'janomy vitsi. Naukova dumka, Kyiv (in Ukrainian).

Nuzhnyi, D. Yu, 2009. The industrial variability of the Eastern Gravettian assemblages of Ukraine. Quartär 56, 159-174.

O'Connor, T., 2000. The Archaeology of Animal Bones. Texas A\&M University Press, College Station.

Olsen, S.J., 1979. Osteology for the Archaeologist: American Mastodon and the Woolly Mammoth; North American Birds: Skulls and Mandibles; North American Birds: Postcranial Skeletons (Papers of the Peabody Museum. Paperback).

Otte, M., 1981. Le Gravettien en Europe Centrale. Dissertationes Archaeologicae Gandenses 20 (Bruges).

Otte, M., Noiret, P., Chirica, V., Borziak, I., 1996. Rythme évolutif du Gravettien Oriental. In: Palma di Cesnola, A., Montet-White, A., Valoch, K. (Eds.), XIII Congrès International d'U.I.S.P.P., Section 6: the Upper Palaeolithic. Colloquim XII. The Origin of the Gravettian. Forli, Italy, pp. 213-226.

Pales, L., Lambert, C., 1971. Atlas ostéologique pour servir à l'identification des mammifères du quaternaire I, 1 et 2, Membres. Éditions du CNRS, Paris.

Pales, L., Garcia, A., 1981. Atlas ostéologique des mammifères. Editions du Centre national de la recherche scientifique, Paris.

Patou-Mathis, M. (Ed.), 1994. Outillage peu élaboré en os et bois de Cervidés. $6^{\text {e }}$ Table Ronde Taphonomie Bone Modification. CEDARC, Paris.

Păunescu, Al, 1999. Paleoliticul ş i epipaleoliticul de pe teritoriul Moldovei cuprins între Siret și Prut. In: Studiu monografic, vol. 1/2 (Bucureşti).

Péan, S., Patou-Mathis, M., 2003. Taphonomy of mammoth sites. In: Reuner, W.F., De Vos, J., Mol, D. (Eds.), Advances in Mammoth Research, Proceedings of the Second International Mammoth Conference, 16-20 May 1999, Rotterdam (PaysBas), pp. 331-345. Deinsea 9.

Poplin, F., 1976. Remarques théoriques et pratiques sur les unités utilisées dans les études d'ostéologie quantitative, particulièrement en archéologie préhistorique. IXe Congrès UISPP, Nice, pp. 124-141.

Reitz, E., Wing, E., 2008. Zooarchaeology. Cambridge University Press, New York.

Renssen, H., Isarin, R.F.B., Vandenberghe, J., 2001. Rapid climatic warming at the end of the last glacial: new perspectives. Global and Planetary Change 30, 155-165.

Roth, V.L., 1984. How elephants grow : Heterochrony and calibration of developmental stages in some living and fossil species. Journal of Vertebrate Paleontology 4 (1), 126-145.

Rountrey, A.N., Fisher, D.C., Tikhonov, A.N., Kosintsev, P.A., Lazarev, P.A., Boeskorov, G., Buigues, B., 2012. Early tooth development, gestation, and season of birth in mammoths. Quaternary International 255, 196-205.

Rudinski, M.Y., 1947. Pushkari. Sovetskaia arkheologiia 9, 171-198 (in Russian).

Rydush, B.T., 2008. Nova pamjatka mobilnogo verchnopaleolitinogo mistctva z podnistrovja. Kamjana doba Ukrainu II, 188-190.

Rusakov, A.V., Korkka, M.A., 2004. The Bryansk fossil soil of the extraglacial zone of the Valday glaciation as an indicator of landscape and soil forming processes in the center of the Russian plain. Revista Mexicana de Ciencias Geologias 21 (1), 94-100.
Sablin, M.V., 1997. Ostatki Mlekopitayushchikh iz Pozdnepaleoliticheskogo Poseleniya Pushkari I. In: Belyaeva, V.I. (Ed.), Pushkarevskii Sbornik. Russian Academy of Sciences, Saint-Petersburg, pp. 35-43 (in Russian).

Schmid, E., 1972. Atlas of Animal Bones. For Prehistorians, Archaeologists and Quaternary Geologists. Knochenatlas. Für Prähistoriker, Archäologen und Quartärgeologen. Drawings by Otto Garraux. Elsevier, New York.

Shoshani, J., Tassy, P., 1996. The Proboscidea: Evolution and Palaeoecology of Elephants and Their Relatives. Oxford Press University, Oxford.

Shovkoplias, I.G., 1967. L'expédition pour la recherche du Paléolithique en 1965 1966. In: Tolotchko, P.P. (Ed.), Les recherches archéologiques en Ukraine dans les années 1965-1966, 1, pp. 56-61 (in Russian).

Sinitsyn, A.A., 2007. Variabilité du Gravettien de Kostienki (Bassin moyen du Don) et des territoires associés. In: Le Gravettien : entités régionales d'une paléoculture européenne. Table ronde, juillet 2004, Les Eyzies, Paléo, 19, pp. 181-202.

Soffer, O., 1985. The Upper Palaeolithic of the Central Russian Plain. Academic Press, Orlando.

Stepanchuk, V.N., 1999. Ecology and cultural development on of territory of Ukraine during Isotopic Stage 2 and 3. In: Vermeersh, R., Renault-Miskovski, J. (Eds.), European Late Pleistocene, Isotope Stage 2 and 3: Humans, Their Ecology and Cultural Adaptation, Actes de la conférence de lÙniversité catholique de Louvain, ERAUL, 90, Liege.

Stupak, D.V., 2010. Nova verknopaleolitichna stojenka Obolonnye v Serednomu Podecenni. Kamjena doba Ukraini 13, 169-178.

Stupak, D.V., 2011. Explorations of Epigravettian Sites in the South of the Middle Desna Area. In: Tolochko, P.P. (Ed.), Ukrainian Archaeology. Institute or archaeology of the National Academy of Sciences of Ukraine, Kiev, pp. 10-25.

Stupak, D.V., Klopatchev, G.A., 2012. Doslidjennie verknopaleolitichnoi stojenki Obolonnye. In: Arkeologicheskie issledovanie v Evroregione "Dnepr" v. 2011, Chernigiv, pp. 103-105.

Stupak, D.V., Klopatchev, G.A., 2013. Nova verknopaleolitichna stojenka Obolonnye. Doslidjennie 2012. In: Arkeologicheskie issledovanie v Evroregione "Dnepr" v. 2012, pp. 196-198.

Stupak, D.V., Khlopachev, G.A., Gribchenko Yu, M., Komar, M.S., 2014. Nova verknopaleolitichna stojenka Obolonnye. In: Stupak, D.V., Khlopachev, G.A. (Eds.), Epigravettian Sites of Middle Dnipro Region. Archaeological Almanac, pp. 9-30, 31.

Vasil'ev, P.M., 2014. New investigations of the Upper Palaeolithic site Pogon (2011$2013)$ pp. 31-50. In: Stupak, D.V., Khlopachev, G.A. (Eds.), Epigravettian Sites of Middle Dnipro Region. Archaeological Almanac, pp. 31-50, 31.

Velichko, A.A., 1961. Region of the Dnieper glaciation (beyond the limits of the Moscow ice sheet). Relief and Quaternary stratigraphy. In: Markov, K.K. (Ed.), Relief and Quaternary Stratigraphy of the Northwestern Russian Plain. The USSR Academy of Sciences Press, Moscow, pp. 173-207 (in Russian).

Velichko, A.A., Morozova, T.D., 1972. The Bryansk fossil soil, its stratigraphical importance and natural conditions of forming. In: Velichko, A.A. (Ed.), Loesses, Fossil Soils and Cryogenic Phenomenon on Russian Plain. Nauka Press, Moscow, pp. 71-114 (in Russian).

Velichko, A.A., Zaverniiaev, F.M., Gribchenko, I.N., Gubonina, Z.P., Zelikson, E.M., Markova, A.K., Udartsev, V.P., 1981. Khotylevskie Stoyanki. In: Gerasimov, I.P. (Ed.), Akheologiia I paleogeografi ia pozdnego paleolita Russkoi pavnini. Nauka, Moscow, pp. 57-69 (in Russian).

Velichko, A.A., Gribchenko, Yu.N., Drenova, A.N., Morozova, T.D., Timireva, S.N., 1997. The Pushkari-Leskonogi key site. In: Velichko, A.A. (Ed.), Loess-soil Formation of the East European Plain. Institute of Geography, Russian Academy of Sciences, Moscow, pp. 43-59 (in Russian).

Velichko, A., Kurenkova, E., 1990. Environmental conditions and human occupation of northern Eurasia during the Late Valdai. In: Soffer, O., Gamble, C. (Eds.), The World at 18,000 BP: High Latitudes, 1. Unwin Hyman, London, pp. 255-265.

Velichko, A.A., Gribchenko, Yu.N., Kurenkova, E.I., Novenko, E.Yu., 1999. Geochronology of the Paleolithic of the East European Plain. In: Gribchenko, Yu.N. Nikolaev, N.I. (Eds.), Changes in Environments and Climates. Animals and Man. Institute of Geography, Russian Academy of Sciences, Moscow, pp. 19-50 (in Russian).

Velichko, A.A., Zelikson, E.M., 2005. Landscape, climate and mammoth food resources in the East European Plain during the Late Paleolithic epoch. Quaternary International 126-128, 137-151.

Voevodski, M.V., 1950. Paleolitieskaie stoienka Pogon. KSIIMK 31, 40-54 (in Russian).

Weinstock, J., 2000. Osteometry as a source of refined demographic information: sex-ratio of Reindeer, hunting strategies, and herd control in the late glacial site of Stellmoor, Northern Germany. Journal of Archaeological Science 27, 1187-1195.

Wilczyński, J., Wojtal, P., Sobczyk, K., 2012. Spatial organization of the Gravettian mammoth hunters site - Kraków Spadzista (southern Poland). Journal of Archaeological Science 39, 3627-3642.

Wojtal, P., Cyrek, K., Sytnik, A., 2001. The new Upper Palaeolithic mammoth site at Halich (Ukraine). Acta zoologica Cracoviensia 44 (2), 137-142.

Zwyns, N., 2004. La problématique de l'Aurignacien tardif dans la zone des steppes nord-pontiques/The late Aurignacian problematic in the north Pontic steppe zone. L'Anthropologie 108, 471-493. 